\title{
A cloud chemistry module for the 3-D cloud-resolving mesoscale model Meso-NH with application to idealized cases
}

\author{
M. Leriche, J.-P. Pinty, C. Mari, and D. Gazen \\ Laboratoire d'Aérologie, CNRS/INSU, UMR5560, Toulouse, France \\ Correspondence to: M. Leriche (maud.leriche@aero.obs-mip.fr) \\ Received: 19 January 2013 - Published in Geosci. Model Dev. Discuss.: 14 February 2013 \\ Revised: 5 July 2013 - Accepted: 8 July 2013 - Published: 22 August 2013
}

\begin{abstract}
A complete chemical module has been developed for use in the Meso-NH three-dimensional cloud resolving mesoscale model. This module includes gaseous- and aqueous-phase chemical reactions that are analysed by a preprocessor generating the Fortran90 code automatically. The kinetic solver is based on a Rosenbrock algorithm, which is robust and accurate for integrating stiff systems and especially multiphase chemistry. The exchange of chemical species between the gas phase and cloud droplets and raindrops is computed kinetically by mass transfers considering non-equilibrium between the gas- and the condensed phases. Microphysical transfers of chemical species are considered for the various cloud microphysics schemes available, which are based on one-moment or two-moment schemes. The $\mathrm{pH}$ of the droplets and of the raindrops is diagnosed separately as the root of a high order polynomial equation. The chemical concentrations in the ice phase are modelled in a single phase encompassing the two categories of precipitating ice particles (snow and graupel) of the microphysical scheme. The only process transferring chemical species in ice is retention during freezing or riming of liquid hydrometeors. Three idealized simulations are reported, which highlight the sensitivity of scavenging efficiency to the choice of the microphysical scheme and the retention coefficient in the ice phase. A two-dimensional warm, shallow convection case is used to compare the impact of the microphysical schemes on the temporal evolution and rates of acid precipitation. Acid wet deposition rates are shown to be overestimated when a onemoment microphysics scheme is used compared to a twomoment scheme. The difference is induced by a better prediction of raindrop radius and raindrop number concentration in the latter scheme. A two-dimensional mixed-phase squall line and a three-dimensional mixed-phase supercell
\end{abstract}

were simulated to test the sensitivity of cloud vertical transport to the retention efficiency of gases in the ice phase. The 2-D and 3-D simulations illustrate that the retention in ice of a moderately soluble gas such as formaldehyde substantially decreases its concentration in the upper troposphere. In these simulations, retention of highly soluble species in the ice phase significantly increased the wet deposition rates.

\section{Introduction}

More than $50 \%$ of the Earth's surface is under cloud and several studies have shown that clouds interact with chemical species in many ways, over a wide range of scales, from micrometres up to thousands of kilometres. On global and regional scales, clouds have a major impact on the composition of the troposphere through multiphase removal processes (Tost et al., 2007). The impact of clouds on the ozone budget and on simple soluble compounds, such as hydrogen peroxide, has been well assessed (Lelieveld and Crutzen, 1991; Monod and Carlier, 1999). However, there are still uncertainties concerning the impact of cloud vertical transport of chemical species by deep convection on the upper troposphere (UT) composition, and about the impact of the chemical reactivity of organic compounds in clouds on the formation of secondary organic aerosol (SOA). For instance, the source of $\mathrm{HO}_{\mathrm{x}}$ in the deep convective tropical cloud outflow needs more investigation since the production of ozone in the UT is almost proportional to the $\mathrm{HO}_{\mathrm{x}}$ mixing ratio (Wennberg et al., 1998; Jaeglé et al., 2001). Moreover, the nucleation of new particles observed downwind of the anvil of deep convective tropical clouds is still uncertain. Discrepancies are observed between in situ measurements 
and theoretical calculations pointing out the possible role of volatile organic compounds associated with sulphur dioxide as precursors of aerosol particles (Waddicor et al., 2012). Organic aerosols affect the earth's radiative budget by their role in both direct and indirect aerosol forcing (Kanakidou et al., 2005). The majority of the organic fraction of aerosols is suspected to be of secondary origin. However, the sources, chemical composition and formation mechanisms of SOA remain one of the least understood processes relevant to the atmosphere (Hallquist et al., 2009). In particular, new routes of SOA formation have been found to comprise the condensation precursors having low volatility that are formed in cloud droplets or raindrops and released in the clear atmosphere when cloud or rain drops evaporate (Chen et al., 2007; Lim et al., 2010; Ervens et al., 2011). However, the potential contribution of the aqueous phase reactivity is highly uncertain, as is the case for the chemical nature of the aqueous phase products that are the precursors of the SOA (Hallquist et al., 2009; Ervens et al., 2011).

The importance of the vertical transport of chemical species by convection has been underlined by many authors (e.g. Dickerson et al., 1987; Prather and Jacob, 1997; Lawrence and Crutzen, 1998; Mari et al., 2000, 2003). In particular, local convection is a major source of $\mathrm{HO}_{\mathrm{x}}$ in the UT (Jaeglé et al., 1998). This production of $\mathrm{HO}_{\mathrm{x}}$ in the UT perturbed by deep convection is mainly due to photochemical reactions of hydrogen peroxide, methyl hydroperoxide, and formaldehyde, which are transported from the boundary layer to the UT by convection or arise from secondary production in the UT (Jaeglé et al., 1997; Cohan et al., 1999). As these species are soluble, they are also impacted by cloud microphysical processes and aqueous phase chemistry (Barth et al., 2007b). Assessing the budgets of $\mathrm{HO}_{\mathrm{x}}$ or SOA thus requires a detailed understanding of the coupling between cloud venting, microphysics and aqueous chemistry.

However, the parameterization of convective transport and gas scavenging at the global scale still remains approximate (Tost et al., 2010) due to the huge number of non-linear processes and the high variability of the solubility and reactivity of the chemical compounds. Meanwhile, at convectiveresolved scale, current computational power enables cloud resolving models (CRM) to be run, where interactions between the cloud microphysics and the chemistry and the advective/turbulent transport of chemical species can be reasonably well detailed (Flossmann and Wobrock, 1996; Barth et al., 2001; Yin et al., 2002). As a result, there is a great need to study and develop an efficient gaseous and aqueous chemical scheme tightly coupled to the microphysics of mixedphase clouds in order to evaluate the budget of chemical compounds after a perturbation caused by convective events.

A CRM is a powerful tool for studying the complex interactions between transport, chemistry and cloud microphysics. Whether they are used for improving the representation of the vertical redistribution of gases and aerosol particles by convective clouds, or to contribute to the assessment of SOA formation by cloud processes, CRMs have to integrate a cloud chemistry module, as well as an aerosol module and detailed cloud microphysics.

In this study, a cloud chemistry module for the threedimensional meteorological model Meso-NH (Lafore et al., 1998) is developed and tested. Among the three ingredients - transport, microphysics and chemistry - the coupling between microphysics and chemistry is the most original part of the package, in particular for cases of mixed-phase cloud. The new module takes advantage of the resolved and turbulent transport schemes and the mixed-phase cloud microphysical scheme, which have been continuously improved, in the host model. Moreover, an aerosol module is available in Meso-NH (ORILAM, for Organic Inorganic Lognormal Aerosol Model, Tulet et al., 2005, 2006), although its coupling with the cloud chemistry module is not presented in the present work.

First, the chemical module is described, including the detailed treatment of the temporal integration of the chemical production and destruction terms and of the cloud microphysics transfer terms. The diagnostic computation of the $\mathrm{pH}$ is also detailed. Then, three applications of the model are presented. The first one is a warm, idealized, two-dimensional precipitating case to focus on the sensitivity of aqueous phase chemistry to the cloud microphysics scheme: one-moment versus two-moment. The second case corresponds to an idealized, two-dimensional squall line to underline the effect of the ice phase on cloud chemistry via the retention of chemical species when riming or freezing occurs. The last case is the simulation of a mixed-phase, three-dimensional supercell, which has been widely studied within the framework of a model intercomparison exercise (Barth et al., 2007a). Finally, some perspectives concerning the use of the full package for simulating complex three-dimensional cloud situations are discussed, together with possible extensions of the module.

\section{Description of the cloud chemistry module}

The cloud chemistry module was implemented in the meteorological Meso-NH model. Meso-NH is a nonhydrostatic mesoscale atmospheric model, which was jointly developed by CNRM (Météo France) and Laboratoire d'Aérologie (CNRS) (Lafore et al., 1998). Meso-NH simulates small-scale (LES with horizontal resolution of a few metres) to synoptic-scale ( $\mathrm{km}$ scale resolution up to several tens of kilometres) phenomena. Different sets of parameterizations have been introduced for convection (Bechtold et al., 2001; Pergaud et al., 2009), cloud microphysics (Pinty and Jabouille, 1998; Cohard and Pinty, 2000a; Khairoudinov and Kogan, 2000), turbulence (Cuxart et al., 2000), surface processes (Noilhan and Mahfouf, 1996; Masson, 2000), gaseous chemistry (Suhre et al., 2000; Tulet et al., 2003), aerosol chemical composition (Tulet et al., 2005, 2006) and cloud 
electricity including, lightning flash production (Barthe et al., 2012). The new cloud chemistry module represents chemistry processes in both warm clouds and mixed-phase clouds.

In nested mode, it is possible to activate the cloud chemistry module in only the inner domain to save computing time while the coupling models ("father" models) treat the gas phase chemistry only.

Continuity equations for a chemical species $X$ (mol per volume of dry air) in the gas phase and in the aqueous phase are of the form

$$
\begin{aligned}
& \frac{\partial X_{\mathrm{g}}}{\partial t}=\left.\frac{\partial X_{\mathrm{g}}}{\partial t}\right|_{\text {dyn }}+\left.\frac{\partial X_{\mathrm{g}}}{\partial t}\right|_{\text {chem }}+\left.\frac{\partial X_{\mathrm{g}}}{\partial t}\right|_{\text {others }} \\
& \frac{\partial X_{\mathrm{w}}}{\partial t}=\left.\frac{\partial X_{\mathrm{w}}}{\partial t}\right|_{\text {dyn }}+\left.\frac{\partial X_{\mathrm{w}}}{\partial t}\right|_{\text {chem }}+\left.\frac{\partial X_{\mathrm{w}}}{\partial t}\right|_{\text {others }} .
\end{aligned}
$$

In Eq. (2), the subscript "w" stands for either cloud droplets or raindrops. In both equations, the term "dyn" refers to dynamical tendencies by advection and turbulence, which applies to all prognostic scalars in the model. The term "others" describes emission, dry deposition and release from the aqueous phase when evaporation, freezing or riming occurs. This point is detailed in Sect. 2.5. For the aqueous phase species, the term others represents the cloud microphysical processes, which depend on the cloud microphysics scheme and are detailed in Sect. 2.2 for warm clouds and in Sect. 2.5 for mixed-phase clouds. Finally, the term "chem" includes gas-liquid transfer and chemical reactions and will be explained in the following subsection. To avoid numerical problems, Eq. (2) is solved only when the liquid water content of cloud water or rainwater goes beyond a threshold value fixed by the user. A typical value is $1 \times 10^{-8} \mathrm{vol} \mathrm{vol}^{-1}$. If the liquid water content is below this value, the concentrations of the chemical species in water are set to zero after transfer to the gas phase. For ions, which are not linked to a gas phase species by dissociation equilibria, the concentrations are set to zero and the associated mass is lost. However, this concerns very few species with very low concentrations (intermediate sulphur species; see below and Table 3).

\subsection{Chemical kinetic scheme}

The evolution of the chemical concentrations in the gas- and liquid phases, denoted by the term chem above, of a chemical species $X$ is given by the generic set of differential equations:

$$
\begin{aligned}
& \left.\frac{\partial X_{\mathrm{g}}}{\partial t}\right|_{\text {chem }}=P_{\mathrm{g}}-D_{\mathrm{g}} X_{\mathrm{g}}-k_{\mathrm{tw}}\left(L_{\mathrm{w}} X_{\mathrm{g}}-\frac{X_{\mathrm{w}}}{H_{\mathrm{eff}} R T}\right) \\
& \left.\frac{\partial X_{\mathrm{w}}}{\partial t}\right|_{\text {chem }}=P_{\mathrm{w}}-D_{\mathrm{w}} X_{\mathrm{w}}+k_{\mathrm{tw}}\left(L_{\mathrm{w}} X_{\mathrm{g}}-\frac{X_{\mathrm{w}}}{H_{\mathrm{eff}} R T}\right) ;
\end{aligned}
$$

$X_{\mathrm{g}}$ and $X_{\mathrm{w}}$ are the concentration of $X$ in the gas phase and the liquid phases, respectively. $P_{\mathrm{g}}$ and $P_{\mathrm{w}}$, and $D_{\mathrm{g}}$ and $D_{\mathrm{w}}$ are the gaseous and the aqueous production terms in mol per volume of dry air $\mathrm{s}^{-1}$, and the gaseous and aqueous destruction terms in $\mathrm{s}^{-1}$, respectively. $L_{\mathrm{w}}$ is the liquid water volume ratio (volume of the drops per volume of air). $H_{\text {eff }}$ is the effective Henry's law constant in mol atm ${ }^{-1} . T$ is the temperature in $\mathrm{K}$ and $R=0.08206 \mathrm{~atm} \mathrm{M}^{-1} \mathrm{~K}^{-1}$ is the universal gas constant. The rate constant of transfer between the gas phase and the aqueous phase $k_{\mathrm{tw}}$ in $\mathrm{s}^{-1}$ is the inverse of the characteristic times for gaseous diffusion and for the interfacial mass transport according to Schwartz (1986):

$k_{\mathrm{tw}}=\left(\frac{a_{\mathrm{w}}^{2}}{3-D_{\mathrm{gas}}}+\frac{4 a_{\mathrm{w}}}{3 \bar{v} \alpha}\right)^{-1}$

$a_{\mathrm{w}}$ is the cloud droplet or raindrop radius in $\mathrm{m}, D_{\text {gas }}$ is the gaseous diffusion coefficient taken equal to $10^{-5} \mathrm{~m}^{2} \mathrm{~s}^{-1}$ for all species, $\bar{v}$ is the mean molecular speed in $\mathrm{m} \mathrm{s}^{-1}$ of the soluble species (see Leriche et al., 2000) and $\alpha$ is the accommodation coefficient of the soluble species. For cloud droplet and raindrop populations, $a_{\mathrm{w}}$ is taken as the mean radius of the respective size distributions. If a one-moment scheme is used, the cloud droplet radius is fixed $\left(a_{\mathrm{w}}=10 \mu \mathrm{m}\right)$ and the mean raindrop radius is diagnosed. Both $a_{\mathrm{w}}$ are computed if a two-moment scheme is chosen.

As a part of the source code solving the chemistry depends on the chemical mechanism, Meso-NH includes a kinetic pre-processor similar to KPP (Damian et al., 2002), which can be applied to any chemical reaction mechanism to automatically generate the Fortran90 code to compute the reaction rates and the Jacobian for the kinetic solver. In the present study, the chemical mechanism for the gas phase chemistry was an updated version of the ReLACS scheme (Regional Lumped Atmospheric Chemical Scheme, originally with 37 prognostic gaseous species and 128 reactions, see Crassier et al., 2000). Compared to the original ReLACS scheme, four prognostic gaseous species were added for the purposes of the aqueous chemistry application (ammonia, sulphuric acid, hydroxyl radical and formic acid), leading to 41 prognostic species in the gas phase. The chemical mechanism developed for the aqueous phase considers 20 soluble compounds, which are exchanged between the gas phase and liquid phases (cloud water and rainwater), and five intermediate ions in the liquid phases describing the sulphur chemistry. The resulting chemical scheme includes gaseous chemical reactions, reactions of mass transfer for the exchange of soluble species between the gas phase and liquid phases, and aqueous chemical reactions. This new scheme is called ReLACS-AQ and includes 91 prognostic species. In the case of mixed-phase clouds, 19 additional prognostic species were added to describe the concentration of soluble species in iceprecipitating hydrometeors (see Sect. 2.5). Photolysis rate coefficients are precalculated in gas phase and in aqueous phase using the Tropospheric Ultraviolet \& Visible Radiation 
Table 1. Values of Henry's law constants at $298 \mathrm{~K}\left(\mathrm{H}_{298}\right)$ and associated temperature dependencies $(\Delta \mathrm{H} / \mathrm{R})$ and values of mass accommodation coefficients $(\alpha)$.

\begin{tabular}{|c|c|c|c|c|c|}
\hline Chemical species & $\mathrm{H}_{298}\left(\mathrm{M} \mathrm{atm}^{-1}\right)$ & $\Delta \mathrm{H} / \mathrm{R}(\mathrm{K})$ & Ref. & $\alpha$ & Ref. \\
\hline $\mathrm{O}_{3}$ & $1.0 \times 10^{-2}$ & -2830 & Sander et al. (2006) & 0.05 & Sander et al. (2006) \\
\hline $\mathrm{OH}$ & $3.9 \times 10^{1}$ & & Sander et al. (2006) & 0.05 & Estimated \\
\hline $\mathrm{HO}_{2}$ & $6.9 \times 10^{2}$ & & Sander et al. (2006) & 0.2 & Sander et al. (2006) \\
\hline $\mathrm{H}_{2} \mathrm{O}_{2}$ & $7.73 \times 10^{4}$ & -7310 & Sander et al. (2006) & 0.11 & Davidovits et al. (1995) \\
\hline NO & $1.92 \times 10^{-3}$ & -1790 & Sander et al. (2006) & 0.0001 & Sander et al. (2006) \\
\hline $\mathrm{NO}_{2}$ & $1.4 \times 10^{-2}$ & & Sander et al. (2006) & 0.0015 & Sander et al. (2006) \\
\hline $\mathrm{NO}_{3}$ & $3.8 \times 10^{-2}$ & & Sander et al. (2006) & 0.05 & Estimated \\
\hline $\mathrm{N}_{2} \mathrm{O}_{5}$ & 2.1 & -3400 & Fried et al. (1994) & 0.0037 & George et al. (1994) \\
\hline $\mathrm{HNO}_{3}$ & $2.1 \times 10^{5}$ & -8700 & Schwartz and White (1981) & 0.054 & Davidovits et al. (1995) \\
\hline $\mathrm{HNO}_{2}$ & $5.0 \times 10^{1}$ & -4900 & Becker et al. (1996) & 0.05 & Bongartz et al. (1994) \\
\hline $\mathrm{HNO}_{4}$ & $1.2 \times 10^{4}$ & -6900 & Régimbal and Mozurkewich (1997) & 0.05 & Estimated \\
\hline $\mathrm{NH}_{3}$ & $6.02 \times 10^{1}$ & -4160 & Sander et al. (2006) & 0.04 & Sander et al. (2006) \\
\hline $\mathrm{SO}_{2}$ & 1.36 & -2930 & Sander et al. (2006) & 0.11 & Sander et al. (2006) \\
\hline $\mathrm{H}_{2} \mathrm{SO}_{4}$ & $2.1 \times 10^{5}$ & -8700 & Estimated as $\mathrm{HNO}_{3}$ & 0.07 & Davidovits et al. (1995) \\
\hline $\mathrm{CO}_{2}$ & $3.4 \times 10^{-2}$ & -2710 & Sander et al. (2006) & 0.0002 & Sander et al. (2006) \\
\hline $\mathrm{CH}_{3} \mathrm{O}_{2}$ & 2.7 & -2030 & Estimated $^{\mathrm{a}}$ & 0.05 & Estimated \\
\hline $\mathrm{CH}_{3} \mathrm{OOH}$ & $3.0 \times 10^{2}$ & -5280 & Sander et al. (2006) & 0.007 & Sander et al. (2006) \\
\hline $\mathrm{HCHO}$ & $3.23 \times 10^{3}$ & -7100 & Sander et al. $(2006)^{b}$ & 0.04 & Sander et al. (2006) \\
\hline $\mathrm{HCOOH}$ & $8.9 \times 10^{3}$ & -6100 & Sander et al. (2006) & 0.012 & Davidovits et al. (1995) \\
\hline $\mathrm{CH}_{3} \mathrm{COOH}$ & $4.1 \times 10^{3}$ & -6300 & Sander et al. (2006) & 0.03 & Sander et al. (2006) \\
\hline
\end{tabular}

a: estimated from the empirical relation $\mathrm{H}_{\mathrm{ROO}_{2}}=\mathrm{H}_{\mathrm{ROOH}} \mathrm{H}_{\mathrm{HO}_{2}} / \mathrm{H}_{\mathrm{H}_{2} \mathrm{O}_{2}}$; ${ }^{\text {: effective value. }}$

Model (TUV, Madronich and Flocke, 1999). The cloud scattering is accounted at every time step of the model following Chang et al. (1987). Moreover, the aqueous phase photolysis reactions are modified for increased path length; a factor of 1.6 is used as in Leriche et al. (2000).

Table 1 lists the chemical species exchanged between the gas- and liquid phases together with the values of their Henry's law constants and accommodation coefficients. Table 2 gives the aqueous phase equilibria, which are used to compute the effective Henry's law constant (except for the HCHO effective Henry's law value, given in Table 1) and the total species mixing ratio in the aqueous phase. The chemical species involved in equilibria are treated as total species to prevent losing mass within an aqueous phase (see Leriche et al., 2000). This approach allows us to treat the $\mathrm{pH}$ as a diagnosed variable (see Sect. 2.4). Finally, Table 3 presents the aqueous phase chemical mechanism of ReLACS-AQ. This mechanism was developed consistently with the gas phase mechanism ReLACS and based upon two existing reduced aqueous phase mechanisms (Tost et al., 2007; CAPRAM2.4 (Chemical Aqueous Phase RAdical Mechanism) from Ervens et al., 2003). The resulting reduced ReLACS-AQ mechanism was tested by comparison with an explicit mechanism and with CAPRAM2.4 in the box model M2C2 (Model of Multiphase Cloud Chemistry; Leriche et al., 2003) using the three scenarios from Ervens et al. (2003): urban, rural and marine. Results of the time evolution of chemical species concentrations showed no significant differences between the full mechanism, the CAPRAM2.4 mechanism and the ReLACS-AQ one (the largest difference was less than $5 \%$ ). As the only source of acetic acid in the aqueous phase in ReLACS-AQ is its mass transfer from the gas phase (no source of its precursors in the aqueous phase), which is of minor importance, its aqueous phase reactivity was neglected.

\subsection{Cloud microphysics transfer terms}

Once dissolved or produced in the drops, the aqueous chemical species are redistributed between the cloud droplets and the raindrops by the cloud microphysical processes that govern the formation, duration and dissipation of clouds. These processes, grouped in the term others of Eq. (2), are autoconversion (AUTO), accretion (ACCR) and sedimentation (SEDI). The transfers of chemical species between liquid drops and gas phase due to condensation/evaporation processes are considered by the transfer terms in Eqs. (3) and (4). Autoconversion and accretion are processes leading to raindrop formation and growth respectively. Autoconversion and accretion processes transfer chemical materials from the cloud droplets to the raindrops. The sedimentation process describes the vertical fluxes of raindrops due to their significant terminal velocity, which ultimately lead to wet deposition of the soluble species by rain. The mass transfer of chemical species due to microphysical processes is computed using the classical assumption that it is proportional to that 
Table 2. Aqueous phase equilibria at $298 \mathrm{~K}\left(\mathrm{~K}_{298}\right)$ and associated temperature dependencies $(\Delta H / R)$.

\begin{tabular}{|c|c|c|c|}
\hline Equilibrium & $\mathrm{K}_{298}(\mathrm{M})$ & $\Delta \mathrm{H} / \mathrm{R}(\mathrm{K})$ & Ref. \\
\hline $\mathrm{HO}_{2} \leftrightarrow \mathrm{H}^{+}+\mathrm{O}_{2}^{-}$ & $1.6 \times 10^{-5}$ & & Bielski et al. (1985) \\
\hline $\mathrm{HNO}_{2} \leftrightarrow \mathrm{H}^{+}+\mathrm{NO}_{2}^{-}$ & $1.6 \times 10^{-3}$ & 1760 & Park and Lee (1988) \\
\hline $\mathrm{HNO}_{3} \leftrightarrow \mathrm{H}^{+}+\mathrm{NO}_{3}^{-}$ & $2.2 \times 10^{1}$ & & Perrin (1982) \\
\hline $\mathrm{HNO}_{4} \leftrightarrow \mathrm{H}^{+}+\mathrm{NO}_{4}^{-}$ & $1.26 \times 10^{-6}$ & & Goldstein and Czapski (1997) \\
\hline $\mathrm{NH}_{3}+\mathrm{H}_{2} \mathrm{O} \leftrightarrow \mathrm{NH}_{4}^{+}+\mathrm{OH}^{-}$ & $1.7 \times 10^{-5}$ & 4350 & Seinfeld and Pandis (1998) \\
\hline $\mathrm{SO}_{2}+\mathrm{H}_{2} \mathrm{O} \leftrightarrow \mathrm{H}^{+}+\mathrm{HSO}_{3}^{-}$ & $1.3 \times 10^{-2}$ & -1965 & Seinfeld and Pandis (1998) \\
\hline $\mathrm{HSO}_{3}^{-} \leftrightarrow \mathrm{H}^{+}+\mathrm{SO}_{3}^{2-}$ & $6.4 \times 10^{-8}$ & -1430 & Seinfeld and Pandis (1998) \\
\hline $\mathrm{H}_{2} \mathrm{SO}_{4} \leftrightarrow \mathrm{H}^{+}+\mathrm{HSO}_{4}^{-}$ & $1.0 \times 10^{3}$ & & Seinfeld and Pandis (1998) \\
\hline $\mathrm{HSO}_{4}^{-} \leftrightarrow \mathrm{H}^{+}+\mathrm{SO}_{4}^{2-}$ & $1.0 \times 10^{-2}$ & & Seinfeld and Pandis (1998) \\
\hline $\mathrm{CO}_{2}+\mathrm{H}_{2} \mathrm{O} \leftrightarrow \mathrm{H}^{+}+\mathrm{HCO}_{3}^{-}$ & $4.3 \times 10^{-7}$ & 920 & Seinfeld and Pandis (1998) \\
\hline $\mathrm{HCO}_{3}^{-} \leftrightarrow \mathrm{H}^{+}+\mathrm{CO}_{3}^{2-}$ & $4.7 \times 10^{-11}$ & 1780 & Seinfeld and Pandis (1998) \\
\hline $\mathrm{HCHO}+\mathrm{H}_{2} \mathrm{O} \leftrightarrow \mathrm{CH}_{2}(\mathrm{OH})_{2}$ & $2.5 \times 10^{3 *}$ & -4030 & Bell (1966) \\
\hline $\mathrm{HCOOH} \leftrightarrow \mathrm{H}^{+}+\mathrm{HCOO}^{-}$ & $1.8 \times 10^{-4}$ & 150 & Serjeant and Dempsey (1979) \\
\hline $\mathrm{CH}_{3} \mathrm{COOH} \leftrightarrow \mathrm{H}^{+}+\mathrm{CH}_{3} \mathrm{COO}^{-}$ & $1.74 \times 10^{-5}$ & & Serjeant and Dempsey (1979) \\
\hline
\end{tabular}

* $\mathrm{K}$ dimensionless

of the microphysical reservoirs. These microphysical transfer terms are computed as follows:

$$
\begin{aligned}
& \left.\frac{\partial X_{\mathrm{c}}}{\partial t}\right|_{\mathrm{AUTO}}=-\left.\frac{\partial X_{\mathrm{r}}}{\partial t}\right|_{\mathrm{AUTO}}=-\left.X_{\mathrm{c}} \frac{1}{r_{\mathrm{c}}} \frac{\partial r_{\mathrm{c}}}{\partial t}\right|_{\mathrm{AUTO}} \\
& \left.\frac{\partial X_{\mathrm{c}}}{\partial t}\right|_{\mathrm{ACCR}}=-\left.\frac{\partial X_{\mathrm{r}}}{\partial t}\right|_{\mathrm{ACCR}}=-\left.X_{\mathrm{c}} \frac{1}{r_{\mathrm{c}}} \frac{\partial r_{\mathrm{c}}}{\partial t}\right|_{\mathrm{ACCR}} \\
& \left.\frac{\partial X_{\mathrm{r}}}{\partial t}\right|_{\mathrm{SEDI}}=-\left.X_{\mathrm{r}} \frac{1}{r_{\mathrm{r}}} \frac{\partial r_{\mathrm{r}}}{\partial t}\right|_{\mathrm{SEDI}}=X_{\mathrm{r}} \frac{1}{r_{\mathrm{r}}} \frac{\partial}{\partial z} F_{\mathrm{SEDI}}\left(r_{\mathrm{r}}\right) ;
\end{aligned}
$$

$r_{\mathrm{c}}$ and $r_{\mathrm{r}}$ are the mass mixing ratios of the cloud droplets and of the raindrops in $\mathrm{kg}$ of water per $\mathrm{kg}$ of dry air, respectively. $F_{\text {SEDI }}$ is the sedimentation flux of the rain mixing ratio.

The sedimentation flux and the autoconversion and accretion rates depend on the cloud microphysical scheme. In Meso-NH, there are four different ways to calculate these terms. The simplest one computes the cloud microphysics with a one-moment scheme following Kessler (1969) and assuming a Marshall-Palmer distribution for the raindrops. The second one uses the one-moment scheme for mixed-phase cloud, ICE3 (Pinty and Jabouille, 1998), which is equivalent, for the warm part of the scheme, to a Kessler (1969) parameterization assuming a generalized gamma distribution for all hydrometeors including rain. The third one, the C2R2 scheme (Cohard and Pinty, 2000a), is a two-moment scheme for warm cloud, in which the parameterization of the $\mathrm{CCN}$ activation follows the diagnostic and integral approach of Twomey (1959), as improved by Cohard et al. (1998). The last one is a two-moment scheme for LES or stratocumulus applications (Khairoudinov and Kogan, 2000). The detailed expressions of each term for the four cloud microphysics schemes available in Meso-NH can be found in the scientific documentation of Meso-NH (http://mesonh.aero.obs-mip.fr/ mesonh/).

Equations (6), (7) and (8) are integrated into the chemical tendencies (Eqs. 1 and 2) before the kinetic solver is called to resolve the chemical ODE system at each grid point of the computational domain.

\subsection{Kinetic solver}

The set of non-linear differential equations describing the evolution of chemical species forms a stiff ODE system (Eqs. 3 and 4). Moreover, including an aqueous phase in the chemical scheme increases the stiffness of the numerical ODE (Audiffren et al., 1998), so we substituted the kinetic solvers available in Meso-NH by the Rosenbrock family of solvers described in Sandu et al. (1997).

Rosenbrock solvers are based on multistage implicit methods with an adaptive sub-time step to achieve high order accuracy. Each stage of the method needs to solve a system of linear equations by inverting a matrix. This is done with an $\mathbf{L U}$-decomposition method (where $\mathbf{L}$ is a lower triangular matrix and $\mathbf{U}$ is an upper triangular matrix) and efficient index coding rules that exploit the sparsity of the Jacobian matrix of the chemical system (only the non-zero coefficients are stored).

Finally, the Rosenbrock solver suite, including multiple order accuracy of the publicly available code of Sandu and Sander (2006), was coupled to the chemistry monitor of Meso-NH. For the sake of efficiency, the solver was adapted in a "vectorized" form such that several independent chemical systems (one per grid point) were solved simultaneously. In order to mix the treatment of cloud-free and aqueous phase 
chemistry, it is useful to order first the gas reactants and then to add the aqueous species.

\section{$2.4 \mathrm{pH}$ solver}

As the solubility of some important gaseous pollutants depends on the $\mathrm{pH}$ (by definition $\mathrm{pH}=-\log 10\left[\mathrm{H}^{+}\right]$) of the drops as well as the aqueous phase reactivity, e.g. in sulphate formation, it is crucial to predict the evolution of the $\mathrm{pH}$ of the cloud droplets and raindrops. There are two ways to solve the $\mathrm{pH}$ in a cloud chemistry module.

The first method explicitly considers all the ionic species by including dissociation equilibria in the aqueous phase chemical mechanism (see Table 2) as backward and forward reactions (e.g. Ervens et al., 2003). Here, the concentration of $\mathrm{H}^{+}$is clearly a prognostic variable. The drawback of this method is the possibility of numerical instabilities. Because backward and forward reactions of dissociation equilibria are very fast, a very small displacement from equilibrium leads to the sporadic occurrence of abnormally high or low concentrations of species, which increases the stiffness of the system.

The second method treats the chemical species involved in equilibria as total species; e.g. formic acid in aqueous phase is the sum of the concentration of the dissolved formic acid plus the concentration of formate ions. Using this formulation, it is possible to set up an electroneutrality equation of the system and then to simplify it by keeping only the main acids and bases. The complex electroneutrality equation was further developed into a high-order polynomial equation for which the concentration of $\mathrm{H}^{+}$was the physical root to be selected. This operation was carefully conducted using formal calculus software to avoid errors of manipulation. The simplified form of the electroneutrality equation deduced from the ReLACS-AQ mechanism is

$$
\begin{aligned}
& {\left[\mathrm{H}^{+}\right]+\left[\mathrm{NH}_{4}^{+}\right]=\left[\mathrm{OH}^{-}\right]+\left[\mathrm{HCO}_{3}^{-}\right]+2\left[\mathrm{CO}_{3}^{2-}\right]+} \\
& {\left[\mathrm{HSO}_{3}^{-}\right]+2\left[\mathrm{SO}_{3}^{2-}\right]} \\
& +\left[\mathrm{NO}_{3}^{-}\right]+2\left[\mathrm{SO}_{4}^{2-}\right]+\left[\mathrm{HCOO}^{-}\right]+\sum[\text { ions }] .
\end{aligned}
$$

The ions in the last term are the intermediate ions of sulphur chemistry (see Table 3), which exist only in aqueous phases and are explicitly represented in the mechanism.

Using the dissociation constants (Table 2) to replace ionic concentrations by concentrations of total species and assuming that strong acids (nitric and sulphuric) are completely dissociated, Eq. (9) leads to a polynomial equation in $\mathrm{H}^{+}$ concentration of degree 8. A Laguerre method (Press et al., 2007) is used to extract the physical root of Eq. (9). A flag allows the $\mathrm{pH}$ to be computed or a constant value to be preset for the $\mathrm{pH}$.

\subsection{Extension to the ice phase}

In mixed-phase clouds, additional processes need to be considered for the soluble chemical species. These include direct gas uptake by ice crystals, partitioning during the freezing or riming of liquid hydrometeors, and the surface and bulk reactions in/on ice hydrometeors. Gas uptake by ice crystals is a complex process because the surface of ice crystals grows continuously by vapour deposition or evaporates (Pruppacher and Klett, 1997). A simple way of parameterizing this process is to introduce a single parameter, the burial coefficient, to describe different efficiencies of gas trapping in growing ice hydrometeors (Yin et al., 2002). The partitioning of soluble gases during the freezing or riming of liquid hydrometeors is classically described by a retention coefficient that partitions the fraction of a dissolved trace gas that is retained in hydrometeors during freezing/riming. Finally, information is almost non-existent for the surface and bulk reactivity of chemical species in the ice crystals and concerns mainly stratospheric conditions (Sander et al., 2006); ice reactivity is traditionally not considered in mixed-phase cloud modelling. However, this reactivity in ice has to be considered in long-term cirrus cloud chemistry modelling (Pruppacher and Klett, 1997).

A very recent modelling study of interactions between chemistry and mixed-phase cloud microphysics (Long et al., 2010) confirms the results obtained by Yin et al. (2002): the main process to be considered in the evolution of chemical species concentrations in mixed-phase clouds is the retention of soluble gases when liquid hydrometeors freeze/rime. Long et al. (2010) found that gas trapping in ice hydrometeors is negligible with, for gas phase, a rate about 1000 times lower than rate due to degassing through retention. This is why the process of gas trapping in growing ice hydrometeors is not considered in the present version. The mixed-phase cloud microphysics scheme available in Meso-NH, ICE3, considers three ice hydrometeor categories: pristine ice, which is newly formed crystals, snow and graupel, defined by an increasing degree of riming. The pristine ice category is not included in the riming processes. This means that the amount of liquid water transferred in this category by microphysical processes is so insignificant that we consider no source of chemical species in the cloud chemistry module for this category of ice.

In order to limit the number of prognostic variables, the concentrations of chemical species in snow and graupel are not differentiated but treated as a single set of species $X_{\text {ice }}$ :

$X_{\text {ice }}=X_{\text {snow }}+X_{\text {grau }}$.

$X_{\text {ice }}, X_{\text {snow }}$ and $X_{\text {grau }}$ are the global concentrations of species $X$ in total ice, the concentration of species $X$ in snow and the concentration of species $X$ in graupel, respectively. $X_{\text {ice }}$ is the prognostic variable with a continuity equation analogous to Eqs. (1) and (2). 
Table 3. Aqueous phase chemical mechanism.

\begin{tabular}{|c|c|c|c|}
\hline Reaction & $k_{298}\left(\mathrm{M}^{-n+1} \mathrm{~s}^{-1}\right)$ & $E_{\mathrm{a}} / \mathrm{R}(\mathrm{K})$ & Ref. \\
\hline $\mathrm{H}_{2} \mathrm{O}_{2}+\mathrm{h} v \rightarrow 2 \mathrm{OH}$ & Calculated & & Graedel and Weschler (1981), Zellner et al. (1990) \\
\hline $\mathrm{OH}+\mathrm{OH} \rightarrow \mathrm{H}_{2} \mathrm{O}_{2}$ & $3.6 \times 10^{9}$ & 930 & Elliot (1989) \\
\hline $\mathrm{OH}+\mathrm{HO}_{2} \rightarrow \mathrm{H}_{2} \mathrm{O}+\mathrm{O}_{2}$ & $2.8 \times 10^{10}$ & 0 & Elliot and Buxton (1992) \\
\hline $\mathrm{OH}+\mathrm{O}_{2}^{-} \rightarrow \mathrm{HO}^{-}+\mathrm{O}_{2}^{-}$ & $3.5 \times 10^{10}$ & 720 & Elliot and Buxton (1992) \\
\hline $\mathrm{H}_{2} \mathrm{O}_{2}+\mathrm{OH} \rightarrow \mathrm{H}_{2} \mathrm{O}+\mathrm{HO}_{2}$ & $3.2 \times 10^{7}$ & 1700 & Yu and Barker (2003), Seinfeld and Pandis (1998) \\
\hline $\mathrm{HO}_{2}+\mathrm{HO}_{2} \rightarrow \mathrm{H}_{2} \mathrm{O}_{2}+\mathrm{O}_{2}$ & $8.3 \times 10^{5}$ & 2700 & Bielski et al. (1985) \\
\hline $\mathrm{HO}_{2}+\mathrm{O}_{2}^{-}+\mathrm{H}_{2} \mathrm{O} \rightarrow \mathrm{H}_{2} \mathrm{O}_{2}+\mathrm{O}_{2}+\mathrm{OH}^{-}$ & $9.6 \times 10^{7}$ & 910 & Christensen and Sehested (1988) \\
\hline $\mathrm{O}_{3}+\mathrm{O}_{2}^{-}+\mathrm{H}_{2} \mathrm{O} \rightarrow \mathrm{OH}+2 \mathrm{O}_{2}+\mathrm{OH}^{-}$ & $1.5 \times 10^{9}$ & 1500 & Seinfeld and Pandis (1998) \\
\hline $\mathrm{OH}+\mathrm{HSO}_{3}^{-} \rightarrow \mathrm{SO}_{3}^{-}+\mathrm{H}_{2} \mathrm{O}$ & $2.7 \times 10^{9}$ & & Buxton et al. (1996) \\
\hline $\mathrm{HNO}_{2}+\mathrm{OH} \rightarrow \mathrm{NO}_{2}+\mathrm{H}_{2} \mathrm{O}$ & $1.0 \times 10^{10}$ & & Barker et al. (1970) \\
\hline $\mathrm{NO}_{2}+\mathrm{HO}_{2} \rightarrow \mathrm{HNO}_{4}$ & $1.8 \times 10^{9}$ & & Logager and Sehested (1993) \\
\hline $\mathrm{NO}_{2}+\mathrm{O}_{2}^{-} \rightarrow \mathrm{NO}_{4}^{-}$ & $4.5 \times 10^{9}$ & & Logager and Sehested (1993) \\
\hline $\mathrm{HNO}_{4} \rightarrow \mathrm{HO}_{2}+\mathrm{NO}_{2}$ & $2.6 \times 10^{-2}$ & & Goldstein et al. (1998) \\
\hline $\mathrm{NO}_{4}^{-} \rightarrow \mathrm{NO}_{2}^{-}+\mathrm{O}_{2}$ & 1.1 & & Goldstein et al. (1998) \\
\hline $\mathrm{HNO}_{4}+\mathrm{HSO}_{3}^{-} \rightarrow \mathrm{SO}_{4}^{2-}+\mathrm{NO}_{3}^{-}+2 \mathrm{H}^{+}$ & $3.3 \times 10^{5}$ & & Amels et al. (1996) \\
\hline $\mathrm{NO}_{3}^{-}+\mathrm{h} v+\mathrm{H}_{2} \mathrm{O} \rightarrow \mathrm{NO}_{2}+\mathrm{OH}+\mathrm{OH}^{-}$ & Calculated & & Graedel and Weschler (1981), Zellner et al. (1990) \\
\hline $\mathrm{N}_{2} \mathrm{O}_{5}+\mathrm{H}_{2} \mathrm{O} \rightarrow 2 \mathrm{HNO}_{3}$ & $1.0 \times 10^{15}$ & & Estimated \\
\hline $\mathrm{NO}_{3}+\mathrm{SO}_{4}^{2-} \rightarrow \mathrm{NO}_{3}^{-}+\mathrm{SO}_{4}^{-}$ & $1.0 \times 10^{5}$ & & Logager et al. (1993) \\
\hline $\mathrm{NO}_{3}+\mathrm{HSO}_{3}^{-} \rightarrow \mathrm{SO}_{3}^{-}+\mathrm{NO}_{3}^{-}+\mathrm{H}^{+}$ & $1.3 \times 10^{9}$ & 2200 & Exner et al. (1992) \\
\hline $\mathrm{CH}_{3} \mathrm{O}_{2}+\mathrm{CH}_{3} \mathrm{O}_{2} \rightarrow 2 \mathrm{HCHO}+2 \mathrm{HO}_{2}$ & $1.7 \times 10^{8}$ & 2200 & Herrmann et al. (1999) \\
\hline $\mathrm{CH}_{3} \mathrm{O}_{2}+\mathrm{HSO}_{3}^{-} \rightarrow \mathrm{CH}_{3} \mathrm{OOH}+\mathrm{SO}_{3}^{-}$ & $5.0 \times 10^{5}$ & & Herrmann et al. (1999) \\
\hline $\mathrm{CH}_{2}(\mathrm{OH})_{2}+\mathrm{OH}+\mathrm{O}_{2} \rightarrow \mathrm{HCOOH}+\mathrm{HO}_{2}+\mathrm{H}_{2} \mathrm{O}$ & $7.8 \times 10^{8}$ & 1000 & Chin and Wine (1994) \\
\hline $\mathrm{HCOOH}+\mathrm{OH}+\mathrm{O}_{2} \rightarrow \mathrm{CO}_{2}+\mathrm{HO}_{2}+\mathrm{H}_{2} \mathrm{O}$ & $1.0 \times 10^{8}$ & 1000 & Chin and Wine (1994) \\
\hline $\mathrm{HCOO}^{-}+\mathrm{OH}+\mathrm{O}_{2} \rightarrow \mathrm{CO}_{2}+\mathrm{HO}_{2}+\mathrm{OH}^{-}$ & $3.4 \times 10^{9}$ & 1200 & Chin and Wine (1994) \\
\hline $\mathrm{HSO}_{3}^{-}+\mathrm{HCHO} \rightarrow \mathrm{HOCH}_{2} \mathrm{SO}_{3}^{-}$ & $7.9 \times 10^{2}$ & 2900 & Olson and Hoffmann (1989) \\
\hline $\mathrm{SO}_{3}^{2-}+\mathrm{HCHO}+\mathrm{H}_{2} \mathrm{O} \rightarrow \mathrm{HOCH}_{2} \mathrm{SO}_{3}^{-}+\mathrm{OH}^{-}$ & $2.5 \times 10^{7}$ & 2450 & Olson and Hoffmann (1989) \\
\hline $\mathrm{HOCH}_{2} \mathrm{SO}_{3}^{-} \rightarrow \mathrm{HSO}_{3}^{-}+\mathrm{HCHO}$ & $7.7 \times 10^{-3}$ & 9200 & Seinfeld and Pandis (1998) \\
\hline $\mathrm{HOCH}_{2} \mathrm{SO}_{3}^{-}+\mathrm{OH}^{-} \rightarrow \mathrm{SO}_{3}^{2-}+\mathrm{CH}_{2}(\mathrm{OH})_{2}$ & $3.7 \times 10^{3}$ & & Seinfeld and Pandis (1998) \\
\hline $\mathrm{HOCH}_{2} \mathrm{SO}_{3}^{-}+\mathrm{OH}+\mathrm{O}_{2} \rightarrow \mathrm{HO}_{2}+\mathrm{HCOOH}+\mathrm{HSO}_{3}^{-}$ & $3.0 \times 10^{8}$ & & Herrmann (2003) \\
\hline $\mathrm{SO}_{3}^{-}+\mathrm{O}_{2} \rightarrow \mathrm{SO}_{5}^{-}$ & $1.1 \times 10^{9}$ & & Das (2001) \\
\hline $\mathrm{SO}_{5}^{-}+\mathrm{HO}_{2} \rightarrow \mathrm{HSO}_{5}^{-}+\mathrm{O}_{2}$ & $1.7 \times 10^{9}$ & & Buxton et al. (1996) \\
\hline $\mathrm{SO}_{5}^{-}+\mathrm{SO}_{5}^{-} \rightarrow 2 \mathrm{SO}_{4}^{-}+\mathrm{O}_{2}$ & $2.2 \times 10^{8}$ & 2600 & Buxton et al. (1996) \\
\hline $\mathrm{HSO}_{5}^{-}+\mathrm{HSO}_{3}^{-}+\mathrm{H}^{+} \rightarrow 2 \mathrm{SO}_{4}^{2-}+3 \mathrm{H}^{+}$ & $7.1 \times 10^{6}$ & & Seinfeld and Pandis (1998) \\
\hline $\mathrm{SO}_{4}^{-}+\mathrm{H}_{2} \mathrm{O} \rightarrow \mathrm{HSO}_{4}^{-}+\mathrm{OH}$ & $4.6 \times 10^{2}$ & 1100 & Yu et al. (2004) \\
\hline $\mathrm{HSO}_{3}^{-}+\mathrm{O}_{3} \rightarrow \mathrm{HSO}_{4}^{-}+\mathrm{O}_{2}$ & $3.7 \times 10^{5}$ & 5500 & Seinfeld and Pandis (1998) \\
\hline $\mathrm{SO}_{3}^{2-}+\mathrm{O}_{3} \rightarrow \mathrm{SO}_{4}^{2-}+\mathrm{O}_{2}$ & $1.5 \times 10^{9}$ & 5300 & Seinfeld and Pandis (1998) \\
\hline $\mathrm{HSO}_{3}^{-}+\mathrm{H}_{2} \mathrm{O}_{2}+\mathrm{H}^{+} \rightarrow \mathrm{SO}_{4}^{2-}+2 \mathrm{H}^{+}+\mathrm{H}_{2} \mathrm{O}$ & $9.1 \times 10^{7}$ & 3600 & Maaß et al. (1999) \\
\hline
\end{tabular}

The additional microphysical transfer terms due to the retention of soluble gases during freezing/riming are computed as follows:

$$
\begin{aligned}
& \left.\frac{\partial X_{\mathrm{g}}}{\partial t}\right|_{\text {FREEZ }}=\left(1-\text { RET) }\left.X_{\mathrm{w}} \frac{1}{r_{\mathrm{W}}} \frac{\partial r_{\mathrm{W}}}{\partial t}\right|_{\text {FREEZ }}\right. \\
& \left.\frac{\partial X_{\mathrm{W}}}{\partial t}\right|_{\text {FREEZ }}=-\left.X_{\mathrm{w}} \frac{1}{r_{\mathrm{W}}} \frac{\partial r_{\mathrm{w}}}{\partial t}\right|_{\text {FREEZ }} \\
& \left.\frac{\partial X_{\text {ice }}}{\partial t}\right|_{\text {FREEZ }}=\left(\text { RET) }\left.X_{\mathrm{w}} \frac{1}{r_{\mathrm{w}}} \frac{\partial r_{\text {ice }}}{\partial t}\right|_{\text {FREEZ }}\right. \\
& =\left(\text { RET) } X_{\mathrm{W}} \frac{1}{r_{\mathrm{W}}}\left(\left.\frac{\partial r_{\text {snow }}}{\partial t}\right|_{\text {FREEZ }}+\left.\frac{\partial r_{\text {grau }}}{\partial t}\right|_{\text {FREEZ }}\right) .\right.
\end{aligned}
$$

FREEZ refers to freezing and riming processes. RET is the retention coefficient $(0 \leq \mathrm{RET} \leq 1)$. RET $=0$ means that the soluble gas is completely released to the gas phase and is not retained in the ice phase at all. $\mathrm{RET}=1$ means that the soluble gas is fully incorporated into the ice phase. For the chemical species present in the aqueous phase only as ionic species (intermediate ions involved in the oxidation scheme of sulphur dioxide), Eqs. (12) and (13) are applied with $\mathrm{RET}=1$.

Table 4 gives the values of retention coefficients for the soluble gases considered in the ReLACS-AQ scheme. Very few experimental studies exist on the phase partitioning during liquid-to-solid freezing and riming (Iribarne and Pyshnov, 1990a, b; Lamb and Blumenstein, 1987; Snider et al., 1992, 1998; Voisin et al., 2000; von Blohn et al., 2011). A recent theoretical study on chemical retention during dry growth riming (Stuart and Jacobson, 2004) shows that the 
Table 4. Retention coefficients.

\begin{tabular}{lrl}
\hline Chemical species & RET & Ref. \\
\hline $\mathrm{SO}_{2}$ & 0.02 & Voisin et al. (2000) \\
$\mathrm{H}_{2} \mathrm{O}_{2}$ & 0.64 & von Blohn et al. (2011) \\
$\mathrm{NH}_{3}$ & 1 & Voisin et al. (2000) \\
$\mathrm{HNO}_{3}$ & 1 & von Blohn et al. (2011) \\
$\mathrm{H}_{2} \mathrm{SO}_{4}$ & 1 & Stuart and Jacobson (2004) \\
$\mathrm{O}_{3}, \mathrm{NO}, \mathrm{NO}_{2}, \mathrm{NO}_{3}, \mathrm{~N}_{2} \mathrm{O}_{5}, \mathrm{CO}_{2}$ & 0 & Estimated \\
$\mathrm{OH}_{2} \mathrm{CH}_{3} \mathrm{O}_{2}, \mathrm{CH}_{3} \mathrm{OOH}$ & 0.02 & Estimated, same as $\mathrm{SO}_{2} *$ \\
$\mathrm{HO}_{2}, \mathrm{HNO}_{2}, \mathrm{HNO}_{4}, \mathrm{HCHO}, \mathrm{HCOOH}, \mathrm{CH}_{3} \mathrm{COOH}$ & 0.64 & Estimated, same as $\mathrm{H}_{2} \mathrm{O}_{2}{ }^{*}$ \\
\hline
\end{tabular}

effective Henry's law constant is a particularly important forcing factor. According to this work, chemical species with very high effective Henry's law constants (e.g. strong acids) are likely to be fully retained in the ice hydrometeor under all conditions. Highly soluble gases such as strong acids are almost completely dissociated in water so ions are hardly able to leave the liquid phase (von Blohn et al., 2011). This is consistent with the available experimental data on nitric acid (Iribarne and Pyshnov, 1990a; von Blohn et al., 2011), which show a retention coefficient of 1 . For chemical species with lower effective Henry's law constants (e.g. $\mathrm{SO}_{2}$ and $\mathrm{H}_{2} \mathrm{O}_{2}$ ), the $\mathrm{pH}$, temperature, drop size, and air speed around the hydrometeor become important factors in the retention fraction (Stuart and Jacobson, 2004). Following the conclusion of this theoretical approach and using the experimental data available, we chose to estimate the retention coefficient of chemical species using data for $\mathrm{SO}_{2}$ and $\mathrm{H}_{2} \mathrm{O}_{2}$ and according to the value of the effective Henry's law constant. The grouping of species in Table 4 is valid for $\mathrm{pH}$ values between 3 and 5. For the strong acids, a value of 1 was taken as recommended. Additionally, some data for $\mathrm{SO}_{2}$ and $\mathrm{NH}_{3}$, deduced from in situ measurements, were available (Voisin et al., 2000). Finally, it was assumed that the retention coefficient of a slightly soluble gas was zero. Thus, these species were not present in the ice phase.

An important microphysical transfer term of ice phase chemical species was added for the sedimentation of graupel and snow, which contributes to wet deposition:

$$
\begin{aligned}
& \left.\frac{\partial X_{\text {ice }}}{\partial t}\right|_{\text {SEDI }}= \\
& -X_{\text {ice }}\left(\left.\frac{1}{r_{\text {snow }}} \frac{\partial r_{\text {snow }}}{\partial t}\right|_{\text {SEDI }}+\left.\frac{1}{r_{\text {grau }}} \frac{\partial r_{\text {grau }}}{\partial t}\right|_{\text {SEDI }}\right) \\
& \quad=X_{\text {ice }}\left(\frac{1}{r_{\text {snow }}} \frac{\partial}{\partial z} F_{\text {SEDI }}\left(r_{\text {snow }}\right)+\frac{1}{r_{\text {grau }}} \frac{\partial}{\partial z} F_{\text {SEDI }}\left(r_{\text {grau }}\right)\right) .
\end{aligned}
$$

As shown in Table 4, 14 soluble chemical species and 5 intermediate ions have prognostic equations for the ice phase.

Geosci. Model Dev., 6, 1275-1298, 2013

\section{Application to idealized test cases}

Three cases were run to assess the new module in Meso-NH. For all cases, the highly accurate PPM (piecewise parabolic method) scheme was used for the transport of the meteorological and scalar fields. The first case, an idealized, warm, two-dimensional precipitating case, was used to study the sensitivity of the cloud chemistry to available warm cloud microphysical schemes. The second case, an idealized, mixed-phase, two-dimensional squall line, allowed us to assess the sensitivity of the cloud chemistry to the ice phase via the retention of chemical species when riming or freezing occurred. The last one, concerning mixed-phase, threedimensional supercells initialized with warm bubbles, was used to compare results with other CRMs, in particular the WRF-chem model (Barth et al., 2007b).

\subsection{The HaRP case: a 2-D warm shallow convection case}

The "HaRP" test case is an idealized 2-D kinematic simulation from "The Hawaiian Rainband Project" that took place in 1990 (Szumowski et al., 1998). It aims at simulating a highly precipitating cell forced by an idealized, time-varying, non-divergent circulation. The duration of the simulation is 3000 s corresponding to the mean life cycle of the HaRP precipitating cell, which is produced by a narrow $(1 \mathrm{~km})$ wave with a slightly tilting updraught peaking at $8 \mathrm{~m} \mathrm{~s}^{-1}$ after $1500 \mathrm{~s}$. Only advection, cloud microphysics and cloud chemistry are considered in the following simulations. The computational domain extends over $180 \times 60$ grid points with a spacing of $50 \mathrm{~m}$ in the $x$ and $z$ directions $(3000 \mathrm{~m}$ in $z$ and $9000 \mathrm{~m}$ in $x$ ). The concentrations of the chemical species are continuously replenished through the open lateral boundaries in the lowest $250 \mathrm{~m}$, where inflow conditions occur. Two simulations are performed to test the sensitivity of the cloud chemistry module to the cloud microphysics scheme. These simulations have already been performed and described in Cohard and Pinty (2000b), who studied the implementation of the C2R2 cloud microphysics scheme in Meso-NH; no chemistry was run in their study. The first case uses the 

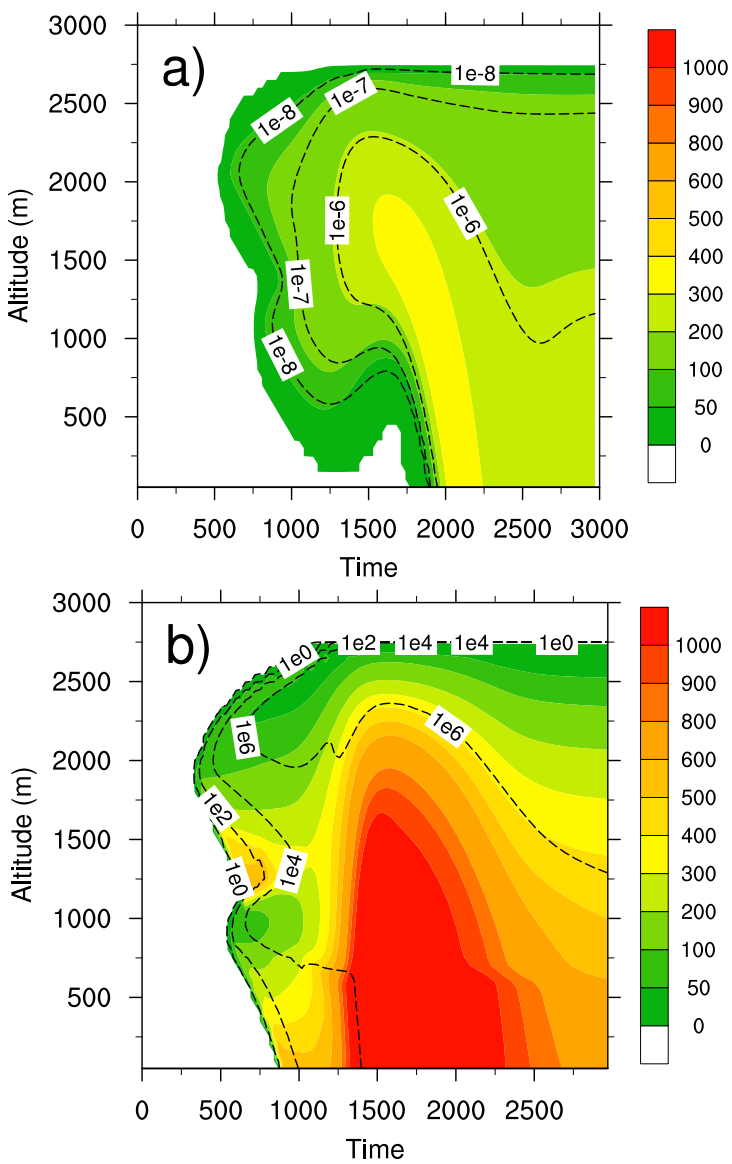

Fig. 1. HaRP case - time evolution of vertical profiles at the centre of the cloud cell for mean raindrop radius $(\mu \mathrm{m})$ : (a) using the Kessler scheme and (b) using the C2R2 scheme. For the Kessler scheme (a), the rain liquid water content $\left(\mathrm{vol} \mathrm{vol}^{-1}\right)$ is superimposed as isolines. For the C2R2 scheme (b), the number concentration of raindrops $\left(\mathrm{L}^{-1}\right)$ is superimposed as isolines.

classical Kessler scheme, which is a one-moment scheme. The second one uses the C2R2 scheme, which includes a realistic parameterization of droplet nucleation described in Cohard et al. (1998). This parameterization is based on a four-parameter $\mathrm{CCN}$ activation spectrum taking into account the physicochemical properties of the accumulation mode in a natural aerosol population.

Cohard and Pinty (2000b) found numerous differences between the Kessler and C2R2 simulations for the HaRP precipitating cell. They found, after $1200 \mathrm{~s}$ of model simulation, that the rain began to reach the ground for the C2R2 case, unlike the Kessler case. At $1500 \mathrm{~s}$ of model simulation, they observed heavy precipitation at sea level for the C2R2 case while the Kessler case produced only a very sharp precipitating band. After $1800 \mathrm{~s}$ of model simulation, the cell began to decay in the C2R2 case while it achieved a maximum development in the Kessler case. Very high radar reflectivity was observed for both cases at the end of the simulation. During a)

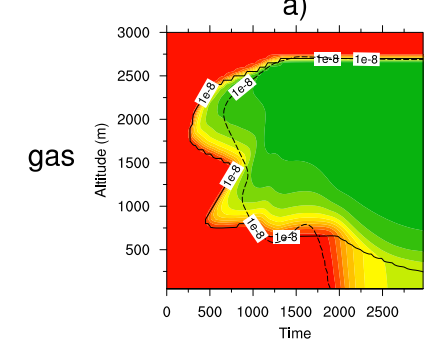

Time
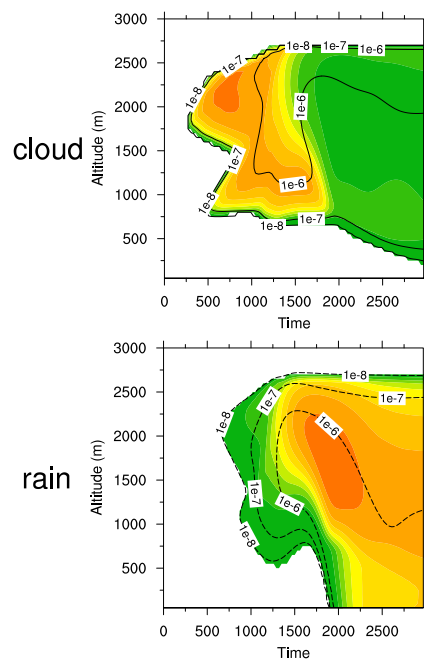

b)
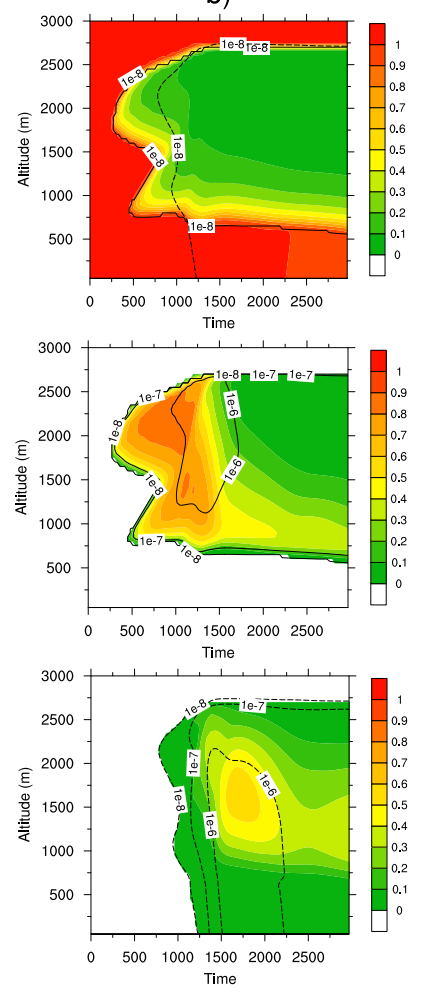

Fig. 2. HaRP case - time evolution of vertical profiles at the centre of the cloud cell for hydrogen peroxide mixing ratio (ppbv) in gas phase, in cloud water and in rainwater: (a) using the Kessler scheme and (b) using the $\mathrm{C} 2 \mathrm{R} 2$ scheme. Isoline of cloud liquid water content ( $\mathrm{vol} \mathrm{vol}^{-1}$, solid line) and of rain liquid water content ( $\mathrm{vol} \mathrm{vol}^{-1}$, dashed line) are superimposed.

the course of the simulation, the rain water content was very high for the Kessler run with values up to $9 \times 10^{-6} \mathrm{vol} \mathrm{vol}^{-1}$, whereas the maximum value was $2.5 \times 10^{-6} \mathrm{vol} \mathrm{vol}^{-1}$ in C2R2 run. Cohard and Pinty (2000b) explained this difference by the presence of an unrealistically small raindrop radius with the Kessler scheme (Fig. 1).

The initial conditions for chemistry are shown in Table 5. These values correspond to a tropical marine atmosphere (Seinfeld and Pandis, 1998; Finlayson-Pitts and Pitts, 2000). Three different types of vertical profiles are allowed. For the "stratospheric vertical profile", the initial mixing ratio is multiplied by 1 from 0 to $2 \mathrm{~km}$ and by 0.5 at $3 \mathrm{~km}$. For the "boundary layer vertical profile", the initial mixing ratio is multiplied by 1 from 0 to $1 \mathrm{~km}$ and by 0.1 from 2 to $3 \mathrm{~km}$. Linear interpolation is used between values given at two levels. Simple DMS chemistry in gas phase, following Mari et al. (1999), is added to the ReLACS chemical scheme.

Results are shown as the time evolution of vertical profiles in the centre of the cloud cell, i.e. the fields have been $x$ averaged over $200 \mathrm{~m}$ in the middle of the domain. For aqueous phase, it is the total species mixing ratio, which is indicated, for instance, for $\mathrm{SO}_{2}$; it is the sum of 
Table 5. Initial gas mixing ratios for the HaRP case. The form of the vertical profile is indicated in parentheses as 1 for homogeneous, 2 for stratospheric, and 3 for boundary layer profile.

\begin{tabular}{llll}
\hline Species & Mixing ratio & Species & Mixing ratio \\
\hline $\mathrm{O}_{3}$ & 40 ppbv (2) & $\mathrm{SO}_{2}$ & 50 pptv (3) \\
$\mathrm{H}_{2} \mathrm{O}_{2}$ & 1 ppbv (1) & $\mathrm{CO}$ & 100 ppbv (3) \\
$\mathrm{NO}$ & 100 pptv (2) & $\mathrm{CH}_{4}$ & 1.7 ppmv (1) \\
$\mathrm{NO}_{2}$ & 100 pptv (2) & $\mathrm{ETH}^{\mathrm{a}}$ & 845 pptv (3) \\
$\mathrm{NO}_{3}$ & 50 pptv (1) & $\mathrm{ALKA}^{\mathrm{b}}$ & 100 pptv (3) \\
$\mathrm{N}_{2} \mathrm{O}_{5}$ & 100 pptv (1) & $\mathrm{ALKE}^{\mathrm{c}}$ & 10 pptv (3) \\
$\mathrm{HNO}_{2}$ & 10 pptv (1) & $\mathrm{BIO}^{\mathrm{d}}$ & 100 pptv (3) \\
$\mathrm{HNO}_{3}$ & 100 pptv (1) & $\mathrm{HCHO}$ & 200 pptv (3) \\
$\mathrm{HNO}_{4}$ & 100 pptv (1) & $\mathrm{KET}^{\mathrm{e}}$ & 100 pptv (3) \\
$\mathrm{NH}_{3}$ & 50 pptv (3) & $\mathrm{PAN}^{\mathrm{f}}$ & 400 pptv (3) \\
$\mathrm{DMS}$ & 100 pptv (3) & $\mathrm{OP}^{\mathrm{g}}$ & 1 ppbv (3) \\
\hline
\end{tabular}

${ }^{\mathrm{a}} \mathrm{ETH}=\mathrm{ethane}^{\mathrm{b}}{ }^{\mathrm{A}} \mathrm{ALKA}=$ alkanes other than methane and ethane, together with alkynes, alcohols, esters and epoxides; ${ }^{\mathrm{c}}$

$\mathrm{ALKE}=$ anthropogenic alkenes; ${ }^{\mathrm{d}} \mathrm{BIO}=$ biogenic species i.e. isoprene, $\alpha$-pinene and d-limonene; ${ }^{\mathrm{e}} \mathrm{KET}=$ acetone and higher saturated ketones; ${ }^{\mathrm{f}} \mathrm{PAN}=$ Peroxyacetal nitrate and higher saturated PANs; ${ }^{\mathrm{g}} \mathrm{OP} 1=$ methyl hydrogen peroxide $\mathrm{CH}_{3} \mathrm{OOH}$.

$\mathrm{SO}_{2}(\mathrm{aq})+\mathrm{HSO}_{3}^{-}+\mathrm{SO}_{3}^{2-}$. For hydrogen peroxide, which is a soluble gas, it is easy to see the effect of wet deposition in the Kessler case (Fig. 2a). At the beginning of the simulation, hydrogen peroxide is scavenged by cloud water and then transferred to rain by microphysical conversion. The sedimentation of the raindrops and the simultaneous scavenging by raindrops lead to its efficient wet deposition. Moreover, during the course of the run, hydrogen peroxide is involved in the oxidation of sulphur dioxide leading to sulphuric acid. This is the main chemical sink of sulphur dioxide occurring in the liquid phase. Contrasting behaviour can be observed for the C2R2 case (Fig. 2b): the microphysical transfer from cloud water to rainwater is limited due to the two-moment approach in C2R2. Such a scheme is able to produce large raindrops in a reasonable concentration, thus with a moderate rainwater content (Fig. 1). Due to the large size of raindrops, the equilibrium time of the mass transfer between the gas phase and the aqueous phase is very long, leading to inefficient scavenging of hydrogen peroxide by raindrops (cf. Eq. 5). This is why the mixing ratio of hydrogen peroxide in rainwater is limited inside the cloud, where collision/coalescence processes transfer chemical species from cloud water to rainwater. These processes are the main source of hydrogen peroxide inside raindrops for the C2R 2 case. For sulphur dioxide, the same disparity can be observed between the Kessler and the C2R2 simulation. Additionally, the form of the initial vertical profile (boundary layer type) is visible (Fig. 3). Also, the mixing ratio of sulphur dioxide exceeds its initial value (50 pptv, see Table 5) in the low levels due to a production by DMS oxidation in the gas phase. Finally, its scavenging by cloud water is delayed compared to hydrogen peroxide because of its lower solubility. Indeed, the
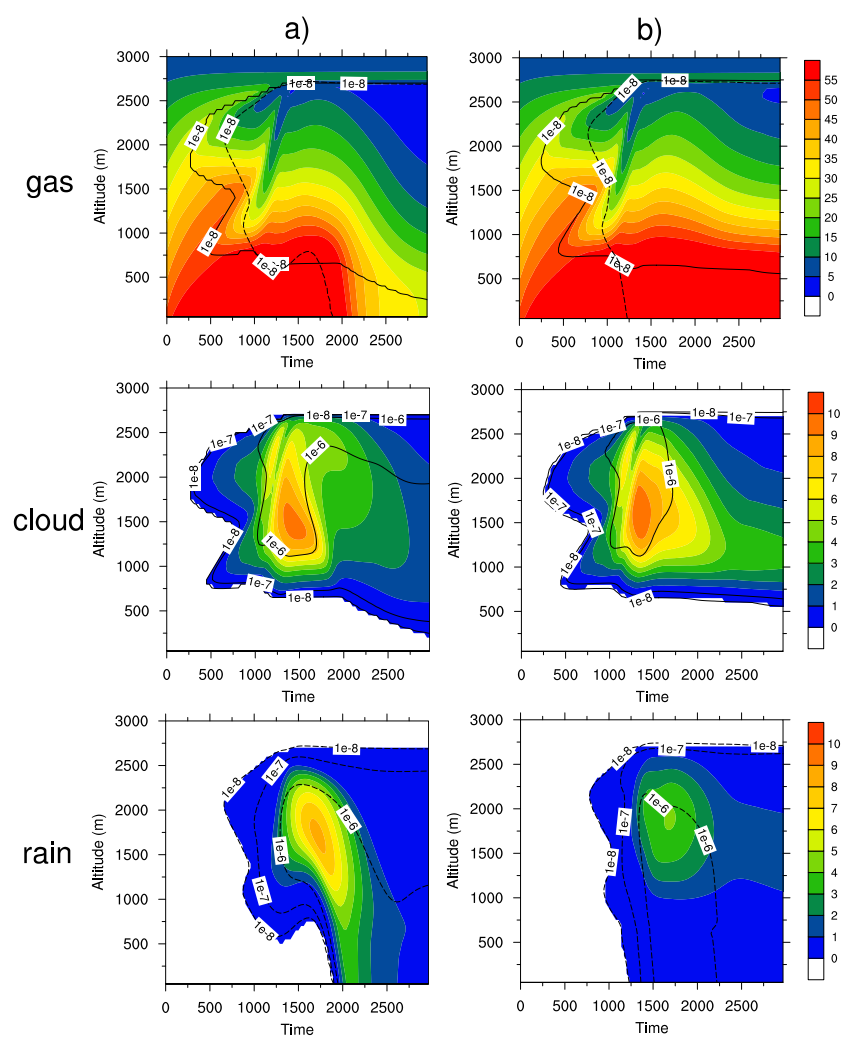

Fig. 3. HaRP case - same as Fig. 2 but for sulphur dioxide (pptv).

effective Henry's law coefficient for sulphur dioxide is between $1.8 \times 10^{2}$ and $5.7 \times 10^{3} \mathrm{M} \mathrm{atm}^{-1}$ in cloud water $(\mathrm{pH}$ value between 4 and 5.5), while it is $7.73 \times 10^{4} \mathrm{M} \mathrm{atm}^{-1}$ for hydrogen peroxide. Because the initial mixing ratio of hydrogen peroxide is larger than that of sulphur dioxide (1 ppbv versus 50 pptv; see Table 5), the oxidation of S(IV) into S(VI) is not limited. No sulphuric acid is present initially. Results for the Kessler case show a production of sulphuric acid up to 38 pptv in rainwater (Fig. 4). However, due to limited transfer of chemical species in rainwater for the C2R2 case, the production of sulphuric acid in rainwater is only up to $16 \mathrm{pptv}$ and is limited inside the cloud (Fig. 4). The resulting $\mathrm{pH}$ simulated for rainwater (Fig. 5) is near the atmospheric equilibrium value considering only the scavenging of carbon dioxide in water (i.e. 5.6). This value is consistent with a remote marine atmosphere (Seinfeld and Pandis, 1998) and is explained by a low production of sulphuric acid, which is counterbalanced by the scavenging of ammonia (initial concentration 50 pptv, see Table 5). Figure 6 , showing the time series in the centre of the cloud at $300 \mathrm{~m}$ of altitude, summarizes these results: below the cloud, for the Kessler case, rainwater is able to efficiently scavenge hydrogen peroxide and sulphur dioxide, which is converted into sulphuric acid in rain. For the $\mathrm{C} 2 \mathrm{R} 2$ case, the scavenging of gases below the cloud is inefficient $\left(\mathrm{SO}_{2}\right.$ mixing ratio in rain is close to zero 
a)
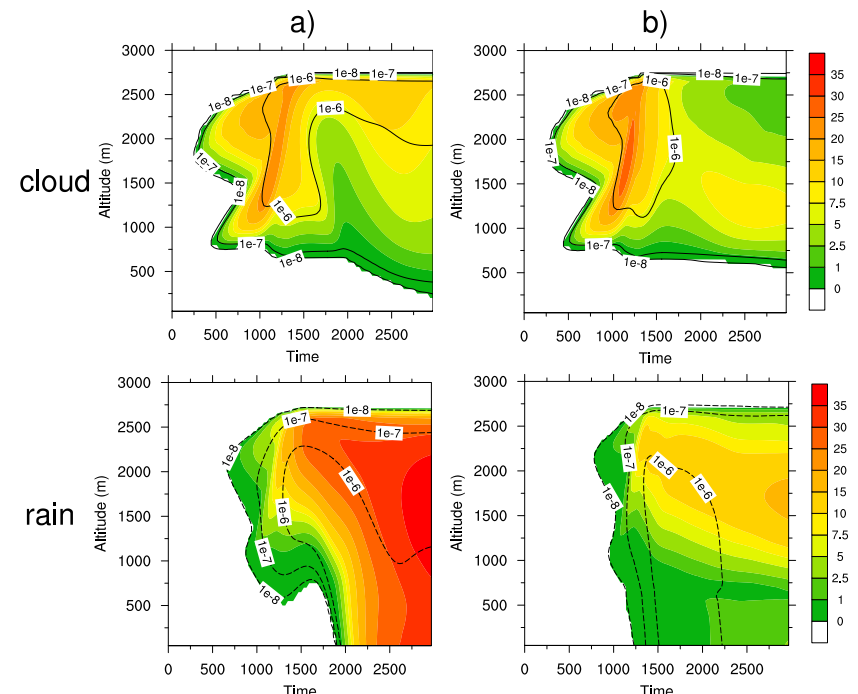

Fig. 4. HaRP case - same as Fig. 2 but for sulphuric acid in cloud water and in rainwater (pptv).

and $\mathrm{H}_{2} \mathrm{O}_{2}$ mixing ratio in rain is very small; see Fig. 6) and the production of sulphuric acid in rainwater is negligible.

This simple idealized simulation highlights the role of the cloud microphysics scheme used in cloud chemistry. In particular, using a two-moment scheme for cloud microphysics allows a better prediction of raindrop number concentration (Fig. 1), leading to a realistic mean raindrop diameter, which greatly changes the assessment of strong acid wet deposition, as the temporal evolution of acid wet deposition rates is very sensitive to the values of raindrop radius. Another important point is the below-cloud aerosol particle scavenging by rain, which is another significant source of strong acid wet deposition. This source is not considered here and should contribute mainly to the acidity of precipitation in a marine atmosphere, where aerosol particles are in the coarse mode, which is the mode more efficiently scavenged by falling raindrops (Berthet et al., 2010.)

\subsection{The COPT case: a 2 -D tropical squall line}

This case is built up from a tropical squall line observed in West Africa during the Convection Profonde Tropicale (COPT81) campaign on 23 June 1981. A tropical squall line is composed of two circulation features: a convective region and a stratiform region. The convective region is characterized by the mesoscale boundary layer convergence feeding deep convective updrafts and mid- to upper-level divergence associated with mass flux outflow from individual cells. The stratiform region is characterized by mid-level convergence feeding both a mesoscale downdraft below the anvil and a mesoscale updraft within the stratiform part. The "COPT" test case (Caniaux et al., 1994) is typically a 12-hour simulation of a tropical squall line with kilometre-scale resolved internal circulations, a 3-D turbulence scheme and
Table 6. Initial gas mixing ratios in the COPT case. The form of the vertical profile is indicated in parentheses as 1 for homogeneous, 2 for stratospheric, and 3 for boundary layer profile.

\begin{tabular}{llll}
\hline Species & Mixing ratio & Species & Mixing ratio \\
\hline $\mathrm{O}_{3}$ & 42 ppbv (2) & $\mathrm{CO}$ & 104 ppbv (3) \\
$\mathrm{H}_{2} \mathrm{O}_{2}$ & 2 ppbv (1) & $\mathrm{CH}_{4}$ & 1.7 ppmv (1) \\
$\mathrm{OH}$ & 0.5 pptv (1) & ETH & 625 pptv (3) \\
$\mathrm{HO}_{2}$ & 30 pptv (1) & ALKA & 767 ptv (3) \\
$\mathrm{NO}$ & 120 pptv (2) & ALKE & 122 pptv (3) \\
$\mathrm{NO}_{2}$ & 550 pptv (2) & BIO & 186 pptv (3) \\
$\mathrm{NO}_{3}$ & 100 pptv (1) & $\mathrm{HCHO}$ & 500 pptv (3) \\
$\mathrm{N}_{2} \mathrm{O}_{5}$ & 35 pptv (1) & ALD & 15 pptv (3) \\
$\mathrm{HNO}_{3}$ & 450 pptv (1) & KET & 957 pptv (3) \\
$\mathrm{NH}_{3}$ & 2.95 ppbv (3) & PAN & 50 pptv (3) \\
$\mathrm{SO}_{2}$ & 363 pptv (3) & OP1 & 750 pptv (1) \\
\hline
\end{tabular}

mixed-phase microphysics (ICE3 scheme). The domain contains $320 \times 44$ grid points unevenly spaced in the vertical $(z=70 \mathrm{~m}$ at ground level and $z=700 \mathrm{~m}$ above $12 \mathrm{~km}$ ). The horizontal resolution is $1.25 \mathrm{~km}$. The model is integrated with a time step of $10 \mathrm{~s}$. A gravity wave damping layer is inserted between $17 \mathrm{~km}$ and the model top at $22.5 \mathrm{~km}$. A constant speed translation is used to compensate for the motion of the squall line. No fluxes are considered in the surface layer. Convection is initiated by forming a $-0.01 \mathrm{~K} \mathrm{~s}^{-1}$ artificial cold pool in the low levels of a small domain for $10 \mathrm{~min}$. Measurements available from the AMMA campaign (Stone et al., 2010) are used to build the initial profiles for chemical species. For unavailable species, the initial profiles are estimated either from simulation by the MOCAGE CTM model (Bousserez et al., 2007; Teyssédre et al., 2007) at the location corresponding to the COPT campaign and for June; or from measurements averaged over June and July for the years 1998 to 2007 and taken from the IDAF database (Adon et al., 2010, http://idaf.sedoo.fr) at Lamto, Ivory Coast. In order to allow short-lived species with unknown concentrations to form and adjust their mixing ratios to an equilibrium state, a simulation with a box model corresponding to $24 \mathrm{~h}$ of spin-up was performed using the set of data composed by AMMA and IDAF measurements as initial conditions, as well as MOCAGE simulation results. The resulting initial mixing ratios in the boundary layer for the COPT case are indicated in Table 6. For the "stratospheric vertical profile", the initial mixing ratio is multiplied by 1 from 0 to $2 \mathrm{~km}$, by 0.5 from 3 to $13 \mathrm{~km}$, by 0.75 at $14 \mathrm{~km}$ and by 1 at $15 \mathrm{~km}$. For the "boundary layer vertical profile", the initial mixing ratio is multiplied by 1 from 0 to $1 \mathrm{~km}$, by 0.1 from 2 to $13 \mathrm{~km}$ and by 0.05 from $14 \mathrm{~km}$ to $15 \mathrm{~km}$. Linear interpolation is used between values given at two levels.

Three simulations are performed. The first one (GAS) considers only gas phase chemistry; the cloud chemistry module is not activated. The second one (AQ-NOICE) neglects the retention of soluble chemical species in the ice phase, 

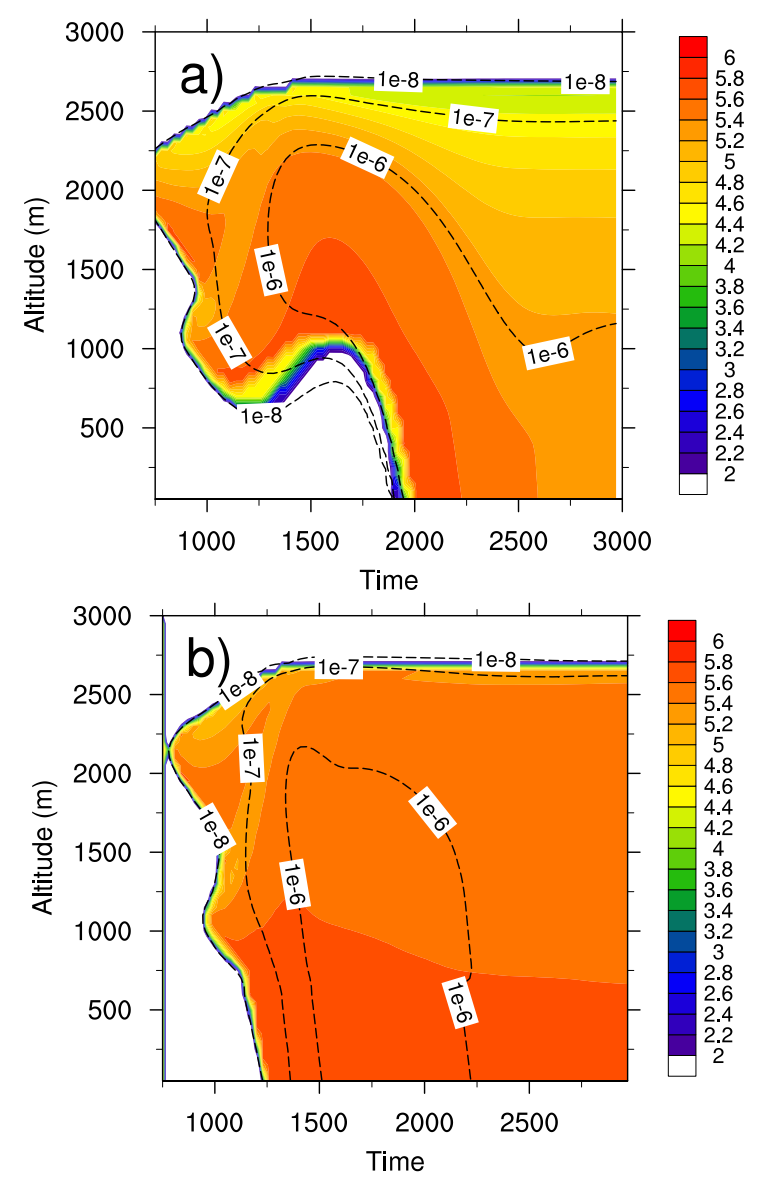

Fig. 5. HaRP case - time evolution of vertical profiles at the centre of the cloud cell for $\mathrm{pH}$ value in rainwater: (a) using the Kessler scheme, and (b) using the C2R2 scheme. The rain liquid water content $\left(\mathrm{vol} \mathrm{vol}^{-1}\right)$ is superimposed as isolines.

assuming that mixing ratios of soluble species in the liquid phase are fully transferred to the gas phase when freezing or riming occurs, which corresponds to RET $=0$ for all species. The third one (AQ-ICE) considers the retention of soluble chemical species in the precipitating ice hydrometeors, i.e. prognostic scalar variables are considered for the mixing ratio of soluble species in ice. Results will be shown in the following as averages obtained between 7 and $8 \mathrm{~h}$ of simulation and corresponding to the mature stage of the squall line (Caniaux et al., 1994), which is characterized by a convective zone $40 \mathrm{~km}$ wide giving large precipitation, a well developed stratiform zone stretching over $150 \mathrm{~km}$ and giving moderate precipitation over an area $80 \mathrm{~km}$ wide, and a forward anvil at the tropical easterly jet level near $12 \mathrm{~km}$.

In this section, we focus on three chemical species with increasing solubility and retention coefficient in the ice phase: formaldehyde $\mathrm{HCHO}$, formic acid $\mathrm{HCOOH}$ and sulphuric acid $\mathrm{H}_{2} \mathrm{SO}_{4}$.

The budget of formaldehyde in the upper troposphere (UT) is still uncertain although $\mathrm{HCHO}$ is a potentially significant
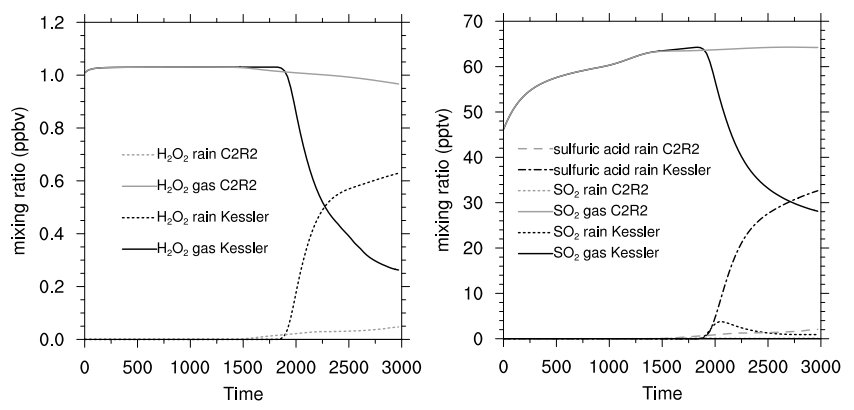

Fig. 6. HaRP case - time evolution of the mixing ratio below the cloud ( $250 \mathrm{~m}$ a.s.1.) for hydrogen peroxide in gas phase and in rainwater (left); and for sulphur dioxide in gas phase and in rainwater, and for sulphuric acid in rainwater (right) for both cases: Kessler (black lines) and C2R2 (grey lines).

source of $\mathrm{HO}_{\mathrm{x}}$ via its photolysis in the UT (Cohan et al., 1999). HCHO observed in the UT is due to direct transfer of boundary layer $\mathrm{HCHO}$ and chemical secondary production by transported VOCs. Fried et al. (2008) and Stickler et al. (2006) showed an HCHO enhancement in the convective outflow for summertime deep convection over North America and the North Atlantic, and in the middle and upper troposphere over Europe, respectively. Borbon et al. (2012) observed a moderate enhancement of $\mathrm{HCHO}$ in the convective outflow for a mesoscale convective system over West Africa. Fried et al. (2008) and Borbon et al. (2012) estimated that $70 \%$ and $60 \%$, respectively, of the HCHO observations in the UT after convection were related to an enhanced production from precursors rather than an upward transport from the boundary layer.

The initial mixing ratio of $\mathrm{HCHO}$ in the boundary layer is $500 \mathrm{pptv}$ (Table 6). For the mature stage of the squall line, this mixing ratio is enhanced due to secondary production of HCHO by the oxidation of VOC (volatile organic compounds) in the front of the squall line, whereas it is reduced behind the passage of the convective front (Fig. 7a-c). This reduction is also observed for CO (not shown), which is a good tracer for convective transport, and is explained by the rear-to-front flow in the low levels of the stratiform area of the squall line. The production of secondary HCHO in the front of the squall line reaches about $100 \mathrm{pptv}$ and comes mainly from the photo-oxidation of alkanes (ETH and ALK ReLACS species) and of methyl hydroperoxide (OP1 ReLACS species) in the gas phase. Indeed, the maximum of the total mixing ratio of HCHO for AQ-NOICE and AQ-ICE simulations (Fig. 7b and c) and of the gas phase mixing ratio of HCHO for the GAS simulation (Fig. 7a) is the same, about 600 pptv. A comparison between Fig. 7a and b shows that the liquid cloud chemistry reduces the vertical transport of HCHO by the convective updraft in the UT due to the scavenging of $\mathrm{HCHO}$ by the cloud droplets and the raindrops. In the GAS simulation, a mixing ratio of $\mathrm{HCHO}$ up to $350 \mathrm{pptv}$ 

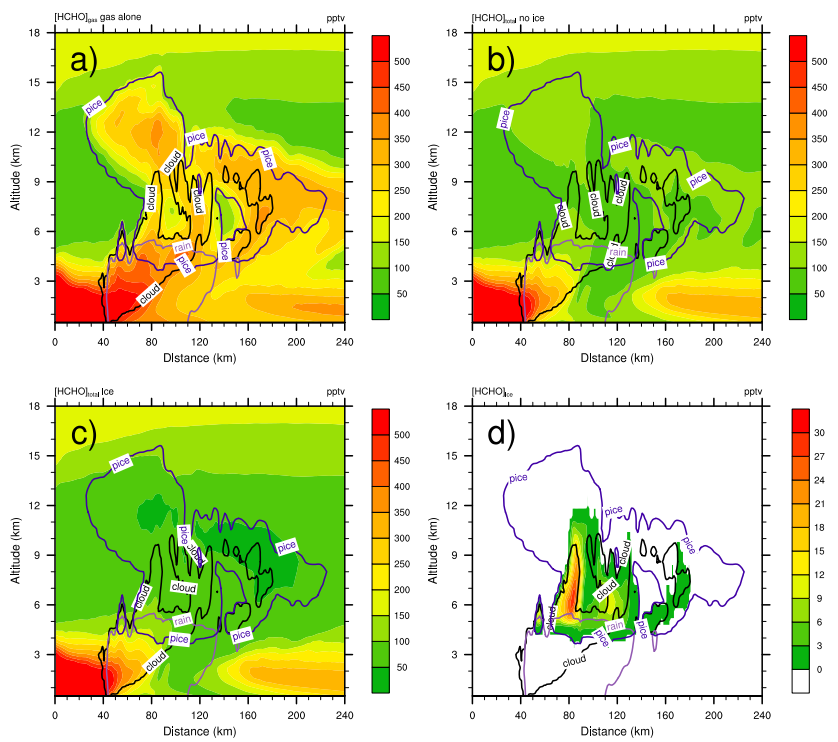

Fig. 7. COPT case - simulated mixing ratio of formaldehyde during the mature stage of the squall line: (a) simulated gas phase mixing ratio of $\mathrm{HCHO}$ for the GAS simulation, (b) simulated total mixing ratio of $\mathrm{HCHO}$ (gas + cloud water + rainwater) for the AQ-NOICE simulation, (c) simulated total mixing ratio of $\mathrm{HCHO}$ (gas + cloud water + rainwater + precipitating ice) for the AQ-ICE simulation, and (d) simulated mixing ratio of $\mathrm{HCHO}$ in precipitating ice for the AQ-ICE simulation. The black line is the $0.01 \mathrm{~g} \mathrm{~kg}^{-1}$ isoline cloud water mixing ratio, the mauve line is that for precipitating ice (snow + graupel), and the purple is that for rainwater.

is observed in the forward anvil and in the stratiform part of the cloud, while it falls below 150 pptv for the AQ-NOICE case. The comparison between the two simulations including cloud chemistry (Fig. 7b and c) is interesting: for AQ-ICE case (Table 4 , RET $=0.64$ for $\mathrm{HCHO}$ ), values of $\mathrm{HCHO}$ in the anvil and in the stratiform part of the cloud are very low, less than $100 \mathrm{pptv}$ with some areas having values less than 50 pptv. The mixing ratio of $\mathrm{HCHO}$ in the ice phase during the mature stage of the cloud is less than 30 pptv (Fig. 7d), so alone it cannot explain the difference between Fig. $7 \mathrm{~b}$ and c. Along the squall line development, the $\mathrm{HCHO}$ in the ice phase is partly eliminated by rain due to the melting of snow and graupel during their sedimentation. This is the main reason for the depletion of HCHO in the gas phase in the UT observed in the AQ-ICE simulation. Non-soluble precursors of HCHO, such as ETH and ALK ReLACS species (respectively ethane and alkanes other than methane and ethane, together with alkynes, alcohols, esters and epoxides), are transported in a similar way to $\mathrm{CO}$ in the forward anvil, the stratiform part of the cloud and the convective outflow. However, their contribution to the HCHO mixing ratio in the UT is very small, as shown by the comparison between Fig. 7c and a. No signature of a secondary production of $\mathrm{HCHO}$ in the UT is observed for the AQ-ICE case. In conclusion, the effect of the retention of $\mathrm{HCHO}$ in ice is to enhance its scavenging
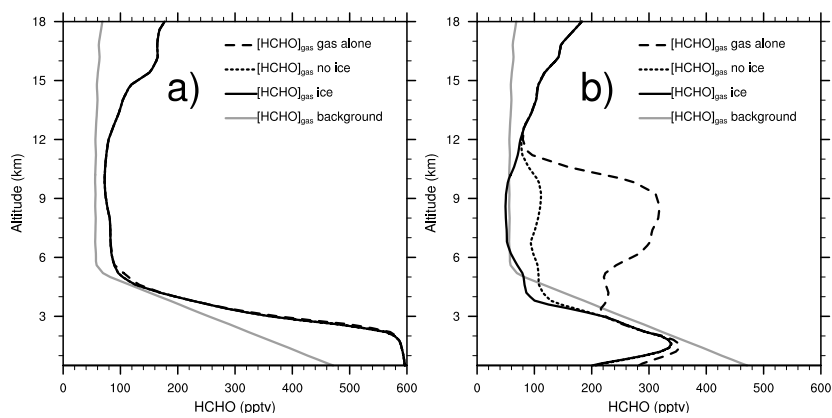

Fig. 8. COPT case - vertical profiles of gas phase mixing ratio of formaldehyde: black lines are mixing ratio for GAS simulation (dashed line), AQ-NOICE simulation (dotted line) and AQ-ICE simulation (solid line), for simulations, and the solid grey line is the mixing ratio for the background troposphere (a) in the inflow region ( $20 \mathrm{~km}$ in horizontal distance) of the squall line during its mature stage and (b) in the outflow region (200 km in horizontal distance) of the squall line during its mature stage.

by the tropical squall line but it leads to a negligible perturbation of $\mathrm{HCHO}$ mixing ratio in the convective outflow. The COPT81 squall line is a very intense convective system with heavy precipitation. The peak of the simulated precipitation rate located below the convective part of the system is about $90 \mathrm{~mm} \mathrm{~h}^{-1}$. Similarly to previous model studies on the transport of soluble species by deep convection using CRM models (Barth et al., 2007a, b; Marécal et al., 2006), results obtained for the AQ-ICE case show a depletion of $\mathrm{HCHO}$ in the convective outflow in comparison with unperturbed UT. This result is consistent with the hypothesis made by previous works based on aircraft observations (Stickler et al., 2006; Fried et al., 2008; Borbon et al., 2012) that direct transport of formaldehyde from the boundary layer by convective updrafts is unlikely. These authors explained the observed HCHO increase in the UT by secondary production from vented precursors. In the COPT81 simulation, however, only 50 pptv of HCHO are produced by transported VOC in the convective outflow, which is not sufficient to compensate for the depletion due to the scavenging by mixed-phase processes (Fig. 7c). Figure 8 shows the vertical profiles of gas phase formaldehyde in the outflow and inflow regions and in the background troposphere. The comparison of the vertical profile in the inflow region and in the background troposphere shows the impact of the dynamic of the squall line in redistributing formaldehyde and its gas phase production in the boundary layer at the front of the squall line. In the outflow region, again the effect of the reduction of the vertical transport of $\mathrm{HCHO}$ by the convective updraft due to cloud chemistry is observed by comparing profiles of AQ-NOICE and AQ-ICE simulations with GAS simulation. In the same way, the enhancement of the scavenging of $\mathrm{HCHO}$ by the squall line through the retention in ice is visible when comparing AQ-NOICE and AQ-ICE vertical profiles (Fig. 8b). 
In conclusion, the vertical profile of $\mathrm{HCHO}$ in the outflow region for the AQ-ICE simulation compares well with the vertical profile given in Fig. 6 of Borbon et al. (2012) study.

Results from global model predict that formic acid originates primarily from the photo-oxidation of biogenic compounds. However, there is still a large uncertainty in the sources of formic acid. To reconcile simulated and observed formic acid mixing ratios, Paulot et al. (2011) reported evidence for a long-lived missing secondary source of carboxylic acids that may be associated with the aging of organic aerosols. In Barth et al. (2007b), formaldehyde was the major precursor of formic acid in the aqueous phase, which was a good tracer of cloud-processed air since its sources in the gas phase are low. Formic acid is a secondary species, both in gas- and aqueous phases. In the gas phase, formic acid is mainly produced in the ReLACS mechanism by the ozonolysis of alkenes (ALKE species in ReLACS) and of biogenic VOC (BIO species in ReLACS). In the aqueous phase, it is produced by the oxidation of hydrated formaldehyde by $\mathrm{OH}$ radical (Table 3). Its main destruction pathway is oxidation by $\mathrm{OH}$ in either the gas or aqueous phase. No formic acid is present initially. As for formaldehyde, a gas phase production is observed in the front of the squall line (Fig. 9a-c). However, in contrast to $\mathrm{HCHO}$ production, the maximum of $\mathrm{HCOOH}$ mixing ratio for the GAS simulation is about 10.5 pptv, whereas it is about $11.6 \mathrm{pptv}$ for the AQNOICE and AQ-ICE cases. This difference is due to a small contribution of aqueous phase chemistry to the gas phase mixing ratio in the front of the squall line. Although a greater production of formic acid via aqueous phase chemistry was expected (the initial mixing ratio of its main precursor in aqueous phase is $500 \mathrm{pptv}$ in the boundary layer), results actually show a very small contribution of cloud reactivity in the net production of formic acid. This is partly explained by the destruction of formate ion by $\mathrm{OH}$ in the aqueous phase, which is more efficient than the oxidation of formic acid by $\mathrm{OH}$ (Table 3). This pathway dominates due to high $\mathrm{pH}$ values in cloud water and rainwater $(\mathrm{pKa}$ (formic acid) $=3.75$ at $298 \mathrm{~K}$; Table 2). Values of $\mathrm{pH}$ were between 6 and 6.5 (not shown) due to a very high mixing ratio of ammonia (almost 3 ppbv in the boundary layer, see Table 6) and low mixing ratio of sulphur dioxide. The effect of the retention of $\mathrm{HCOOH}$ in ice is the same as simulated for HCHO with a depletion of formic acid in the UT (Fig. 9c), which cannot be directly explained by its amount in ice precipitating hydrometeors (Fig. 9d). Barth et al. (2007) found a $\mathrm{HCOOH}$ production of about $100 \mathrm{pptv}$ in the core of the storm where the cloud water is located, whereas, in the COPT case, this production is very low, a few pptv. Two main differences between Barth et al. (2007) and the COPT case in our study explain this discrepancy. First, in Barth et al. (2007), the initial mixing ratio of $\mathrm{HCHO}$, the precursor of $\mathrm{HCOOH}$ in aqueous phase, was about $2 \mathrm{ppbv}$ at the surface, whereas it is $500 \mathrm{pptv}$ in the COPT case. Secondly, in the COPT case, the $\mathrm{pH}$ value in cloud water is high, between 6 and 6.5 whereas it was around
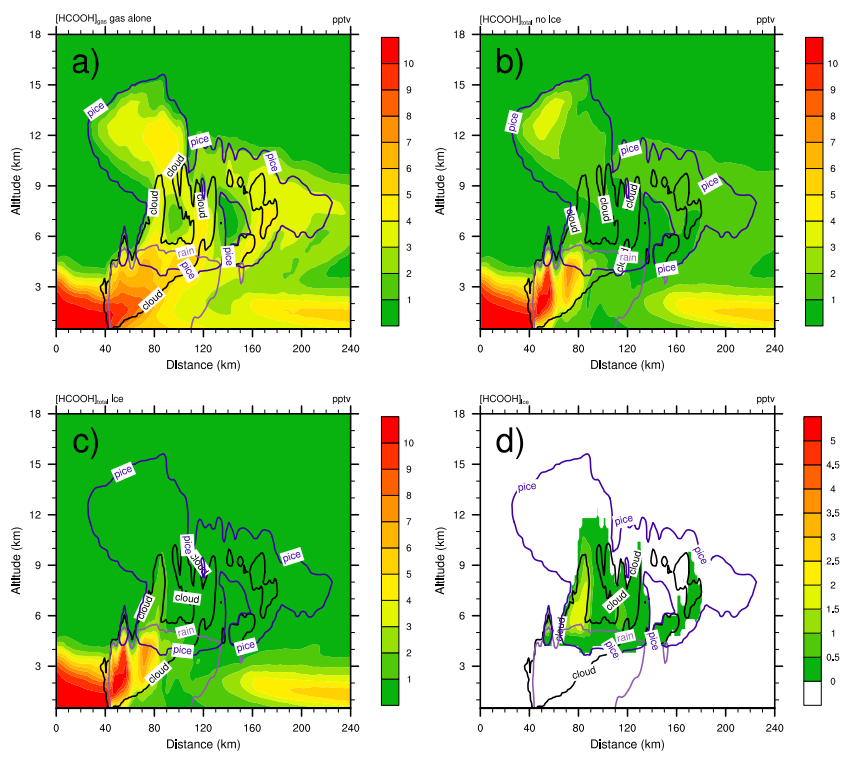

Fig. 9. COPT case - same as Fig. 7 but for formic acid.

4.5 in the simulation of Barth et al. (2007). Thus, the destruction of formic acid is more efficient in our study because the formate ion pathway dominates at high $\mathrm{pH}$ value.

Sulphuric acid is one of the precursors for the nucleation of new aerosol particles in the UT (e.g. Waddicor et al., 2012). Sulphuric acid is a strong acid with a very high Henry's law constant (Table 1). It is completely retained in the ice phase when freezing or riming occurs, with a retention coefficient equal to 1 (Table 4). No sulphuric acid is present initially. Figure 10a shows a very low production of sulphuric acid of less than $1.5 \mathrm{pptv}$ in the gas phase by oxidation of sulphur dioxide by $\mathrm{OH}$ radical. When liquid phase chemistry is activated (Fig. 10b, AQ-NOICE case), the total mixing ratio of sulphuric acid shows two maxima: one located at the base of the squall line with a maximum value of about $280 \mathrm{pptv}$, and another located in the forward anvil of the squall line with a maximum value of about $8 \mathrm{pptv}$. The first maximum is due to the high mixing ratio of sulphuric acid inside cloud water and rainwater, which is produced by the oxidation of sulphur dioxide by ozone and hydrogen peroxide in the aqueous phase. A similar maximum is observed for the AQ-ICE simulation (Fig. 10c). The upper level maximum is in the gas phase and can only be explained by the degassing of supercooled droplets when riming or freezing occurs throughout the AQ-NOICE simulation. For the AQ-ICE case, the mixing ratio in the ice phase at the mature stage of the cloud is about 2 pptv (Fig. 10d) and cannot explain the high maximum located in the forward anvil simulated for the AQNOICE case. Only complex interactions between sulphuric acid degassing from supercooled droplets and its successive transport throughout the simulation can explain this result: the released gaseous sulphuric acid is entrained by the convective updraft inside the forward anvil while the convective 

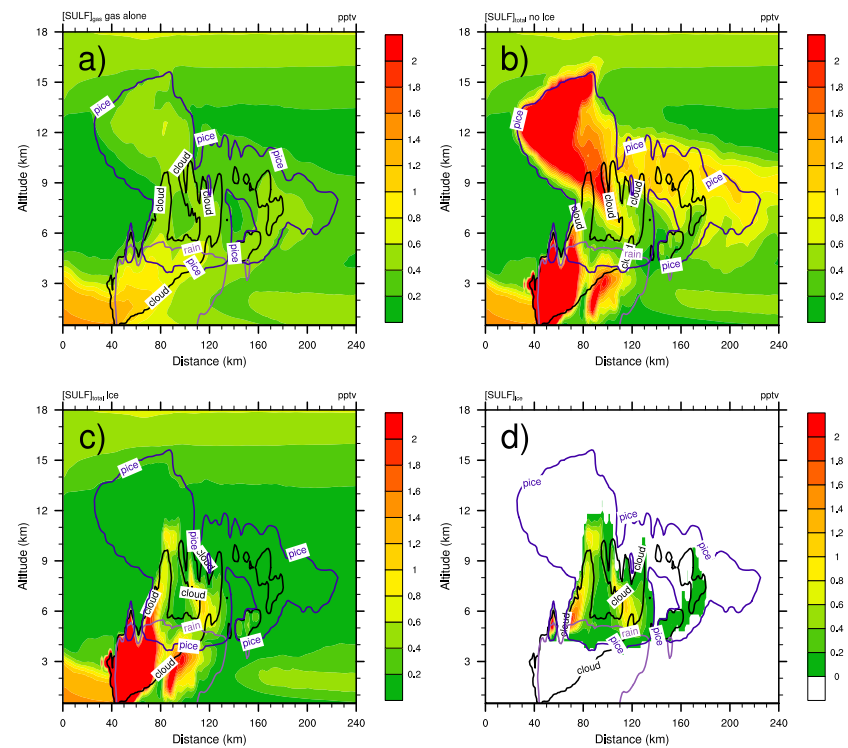

Fig. 10. COPT case - same as Fig. 7 but for sulphuric acid.

cell evolves in a squall line. As already pointed out for formic acid, the AQ-ICE simulation shows a very low mixing ratio of soluble species (here sulphuric acid) inside the forward anvil and the stratiform part of the squall line (Fig. 10d) due to efficient trapping of soluble species inside the iceprecipitating hydrometeors, then contributing to wet deposition.

For this particular simulation, the results show that the effect of the retention of soluble species in the ice phase is to enhance the scavenging efficiency of soluble species and thus to increase the wet deposition of the soluble species. This is consistent with the very high accumulated precipitation due to melting of snow and graupel in the convective part of the cloud.

\subsection{The STERAO case: a 3-D continental storm}

The STERAO (Stratospheric-Tropospheric Experiment: Radiation, Aerosol, and Ozone) convective system observed on 10 July 1996 took place near the southern border of Wyoming and Nebraska (see Dye et al., 2000 for an overview of the experiment). The storm developed during the late afternoon, the main cells propagated south-south-eastward into north-eastern Colorado before dissipating in the evening. Radar reflectivity observations showed an evolution of the storm from a multicell stage followed by a quasi supercellular one (Dye et al., 2000). The simulation of this storm performed with the Meso-NH model is a 3-D idealized run based upon Skamarock et al. (2000) with some modifications. The convection is initiated with three warm bubbles $\left(+3{ }^{\circ} \mathrm{C}\right)$ placed in the wind direction leading to a simulated convective system similar to the one observed. In particular, the transition from a multicellular line to a single supercell is reproduced. The configuration of the model is the same as in Barthe et al. (2012). A $160 \times 160 \mathrm{~km}^{2}$ horizontal domain is used with a $1 \mathrm{~km}$ horizontal resolution. The vertical grid has 51 levels up to $23 \mathrm{~km}$ with a level spacing of $50 \mathrm{~m}$ close to the surface, stretching to $700 \mathrm{~m}$ at the top of the domain. The terrain height is $1.5 \mathrm{~km}$. The time step is $2.5 \mathrm{~s}$ and the simulation lasts for $3 \mathrm{~h}$. For cloud microphysics, the mixed-phase scheme ICE3 is used and, for turbulence, the 3 -D scheme is activated. A simple module for the parameterization of the NO production from lightning is used, following Pickering et al. (1998). However, the production of NO by cloud-to-ground flash and intracloud flash are taken from Barth et al. (2007b). Based upon observations and model results, Barth et al. (2007b) estimated that each cloud-toground flash produced 390 moles of $\mathrm{NO}$ on average and an intracloud flash, 195 moles of NO on average. The model environment is initialized with horizontally homogeneous thermodynamic sounding and chemical vertical profiles. These initial vertical profiles for chemical species $\left(\mathrm{O}_{3}, \mathrm{NO}, \mathrm{NO}_{2}\right.$, $\mathrm{NH}_{3}, \mathrm{HNO}_{3}, \mathrm{CO}, \mathrm{CH}_{4}, \mathrm{HCHO}, \mathrm{H}_{2} \mathrm{O}_{2}, \mathrm{CH}_{3} \mathrm{OOH}$ and $\mathrm{SO}_{2}$ ) were given in Barth et al. (2007a, b) and were estimated from aircraft measurements outside the cloud. VOC precursors of $\mathrm{HCHO}$, apart from methane, are not considered in this simulation.

Results are evaluated in comparison with the simulation reported in Barth et al. (2007b), with particular focus on a comparison of simulations considering or ignoring the retention of soluble species in ice precipitating hydrometeors. In Barth et al.'s (2007b) study, the WRF-Chem model was used in a configuration close to Meso-NH. The main differences between the two models lay in the chemical mechanism and the parameterization of cloud ice phase chemistry. In Barth et al. (2007b), the chemical mechanism predicted the mixing ratio of 16 species and was limited to the chemistry of an ozone- $\mathrm{NO}_{\mathrm{x}}-\mathrm{HO}_{\mathrm{x}}-\mathrm{CH}_{4}-\mathrm{SO}_{2}$ system with 28 chemical reactions in the gas phase, the exchange of 16 species between gas- and aqueous phases and 15 reactions in the aqueous phase. In the aqueous phase, the reactivity of $\mathrm{NO}_{\mathrm{y}}$ species was not considered. For the interaction with the ice phase of the cloud, two simulations were performed in Barth et al. (2007b): either dissolved species were completely retained in the ice phase when cloud droplets, or raindrops froze $(\mathrm{RET}=1)$ or all dissolved species were degassed during freezing $(\mathrm{RET}=0)$.

As shown in Barth et al. (2007b), CO is transported from the boundary layer to the anvil of the cloud where mixing ratios are $>110 \mathrm{ppbv}$, greater than the unperturbed UT at the same level (Fig. 11a and b). As in Barth et al. (2007b), the comparison of $\mathrm{CO}$ and ozone with measurements across the anvil are in good agreement (not shown). Results are now discussed for $\mathrm{HCHO}$ and $\mathrm{H}_{2} \mathrm{O}_{2}$, two soluble and reactive gases. For $\mathrm{HCHO}$, the results are shown at $1 \mathrm{~h}$, corresponding to the multicell stage of the cloud.

Despite its solubility and its reactivity in the aqueous phase, $\mathrm{HCHO}$ is efficiently transported from the boundary 

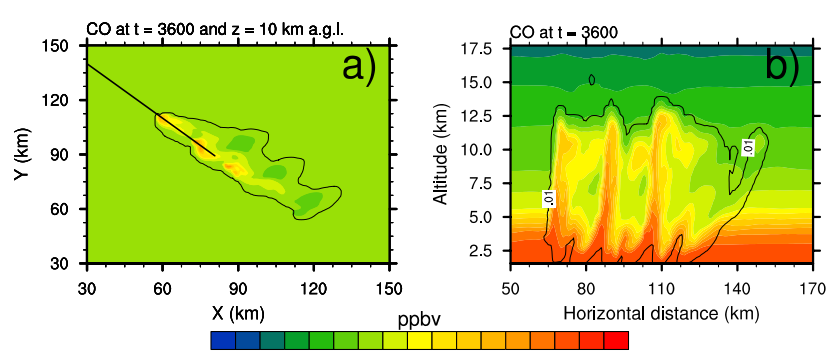

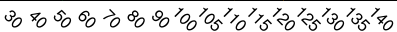

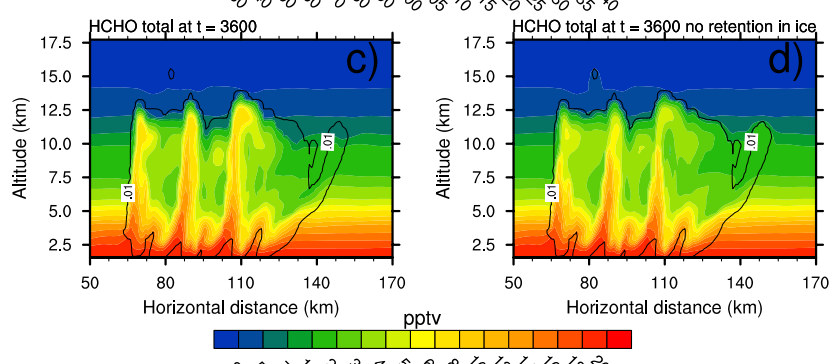

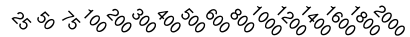

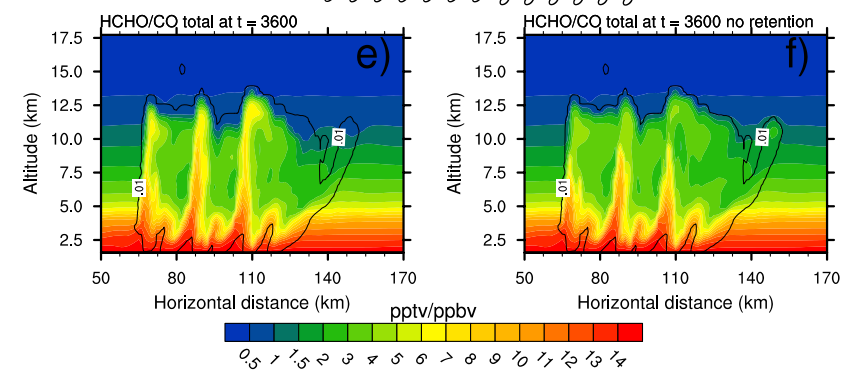

Fig. 11. STERAO case - results at $t=3600 \mathrm{~s}$ for (a) horizontal cross section of CO mixing ratio in ppbv at $10 \mathrm{~km}$ a.g.l., (b) vertical cross section along the segment indicated on (a) for $\mathrm{CO}$ mixing ratio in ppbv, (c) same vertical cross section for HCHO total mixing ratio (gas + cloud water + rainwater + precipitating ice) in pptv for simulation with retention in ice, (d) same as (c) for simulation without retention in ice, (e) same vertical cross section for the ratio of total $\mathrm{HCHO}$ to $\mathrm{CO}$ in pptv ppbv ${ }^{-1}$ for simulation with retention in ice, and (f) same as (e) for simulation without retention in ice.

layer to the anvil (Fig. 11c and d) during the multicell stage of the cloud. However, the total mixing ratio of $\mathrm{HCHO}$ in the anvil is greater for the simulation considering retention in ice (Fig. 11c) than in the one with no retention (Fig. 11d). $\mathrm{HCHO}$ and $\mathrm{CO}$ have the same initial vertical profile but with different magnitudes. It is thus interesting to compare the redistribution by the cloud of $\mathrm{HCHO}$, a soluble and reactive species, and that of $\mathrm{CO}$, an insoluble passive species. Consistently with results for the total mixing ratio of $\mathrm{HCHO}$, the ratio of total $\mathrm{HCHO}$ to $\mathrm{CO}$ shows a transport of $\mathrm{HCHO}$ from the boundary layer to the anvil, which is efficient in the simulation with retention in ice. The ratio of total $\mathrm{HCHO}$ to $\mathrm{CO}$ also reveals that vertical transport inside the cloud is less efficient for $\mathrm{HCHO}$ than for $\mathrm{CO}$, indicating that a fraction of $\mathrm{HCHO}$ has reacted or precipitated to the ground. This effect described in Barth et al. (2007b) is similar. Looking at the gas phase mixing ratio of $\mathrm{HCHO}$ (Fig. 12a and b), the simulated
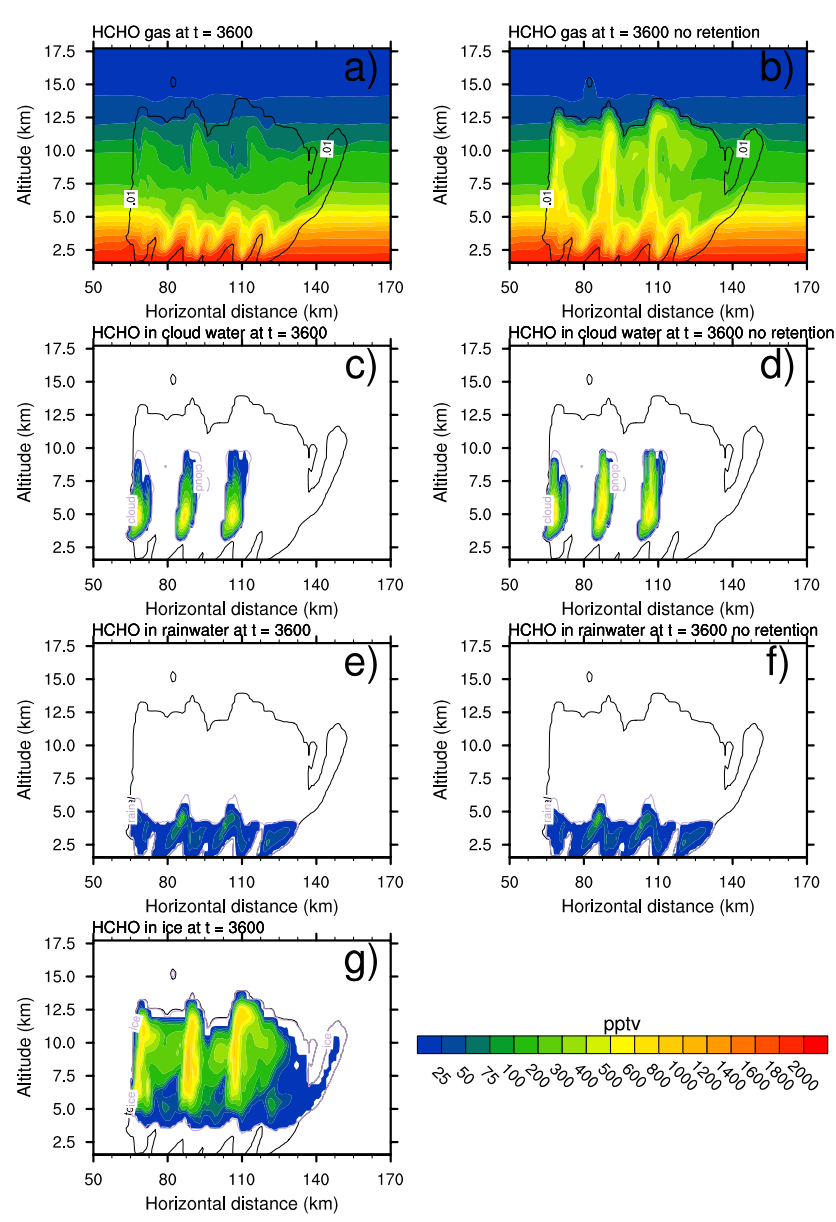

Fig. 12. STERAO case - results at $t=3600 \mathrm{~s}$ for vertical cross section of HCHO mixing ratio in pptv along the segment indicated in Fig. 10a, left hand side, for simulation with retention in ice, and right hand side for simulation without retention: (a) and (b) in gas phase, (c) and (d) in cloud water, (e) and (f) in rainwater, and (g) in precipitating ice. The black line represents the total hydrometeors mixing ratio equal to $0.01 \mathrm{~g} \mathrm{~kg}^{-1}$, the grey line in (c) and (d) is the same for cloud water, the grey line in (e) and (f) is the same for rainwater, and the grey line in $(\mathbf{g})$ is the same for precipitating ice.

gas phase mixing ratio of $\mathrm{HCHO}$ in the anvil is low in the simulation with retention in ice whereas an efficient transport of $\mathrm{HCHO}$ in the anvil is observed for the simulation without retention. As shown by Fig. 13, a relatively small depletion of gas phase $\mathrm{HCHO}$ in the convective outflow is found in comparison with unperturbed UT for the simulation with retention in ice. This effect is similar to the COPT case. For the simulation without retention in ice, the effect is negligible in the UT. These results are in agreement with Barth et al. (2007b). The mixing ratios of HCHO in cloud water and in rainwater (Fig. 12c-f) for both simulations are very close, with a difference at the top of the cloud water zone due to less HCHO being available in the gas phase at this altitude in the simulation with retention. In the simulation without 


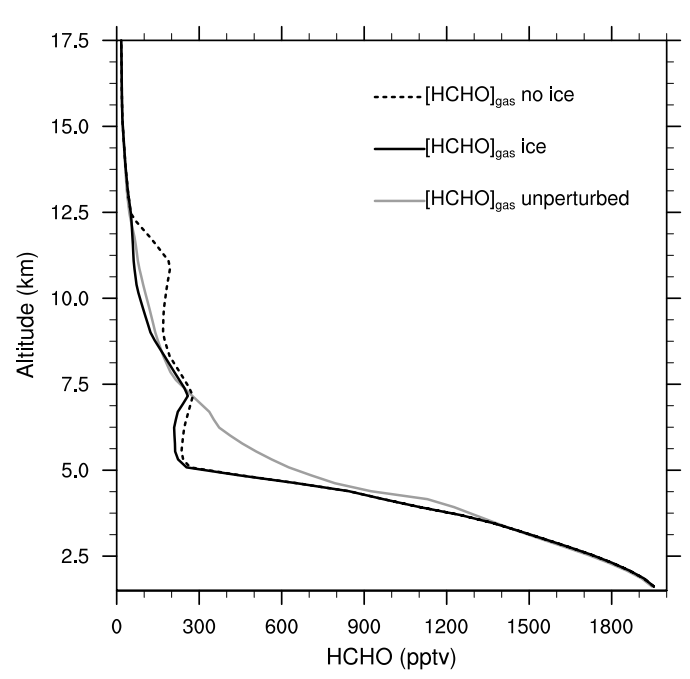

Fig. 13. STERAO case - vertical profiles of gas phase mixing ratio of formaldehyde: black lines are mixing ratio in the convective outflow (135 km in horizontal distance in reference to Fig. 12a and b) for simulation with retention in ice (solid line), and for simulation without retention (dotted line). The solid grey line is the mixing ratio for the unperturbed troposphere.

retention, HCHO degasses when freezing occurs, and is absorbed subsequently by the supercooled cloud water at the top of the updraft. This result was already found by Barth et al. (2001) in their simulation with no retention for all soluble trace gases. In comparison to Barth et al. (2007b), the same order of magnitude is retrieved for the HCHO mixing ratio in cloud water but lower values are observed in rainwater. In Barth et al. (2007b), the mixing ratios of soluble species were explicitly represented in each of the ice phase hydrometeor categories. However, the comparison of the sum of $\mathrm{HCHO}$ mixing ratios in snow and in hail categories from Barth et al. (2007b) with the HCHO mixing ratio in precipitating ice from our simulation (Fig. 12g) shows the same order of magnitude. Thus, the global approach for the ice phase species mixing ratio representation used in Meso-NH seems to be comparable to a more explicit approach. The main general remarks concern results of HCHO mixing ratio during the supercell stage of the cloud (after $2.5 \mathrm{~h}$ of simulation). In particular, the depletion of gas phase mixing ratio of $\mathrm{HCHO}$ in the convective outflow is again observed for the simulation with retention in ice, whereas the simulation without retention shows enrichment in the anvil (not shown). This difference is due to the capture of HCHO in the ice phase. The greater value of total HCHO mixing ratio observed for the simulation with retention in ice whatever the stage of the storm in comparison to simulation without retention indicates the formation of a reservoir of $\mathrm{HCHO}$ in the ice phase in the simulation with retention in ice, leading to less HCHO remaining available to react in the gas- and aqueous phases.
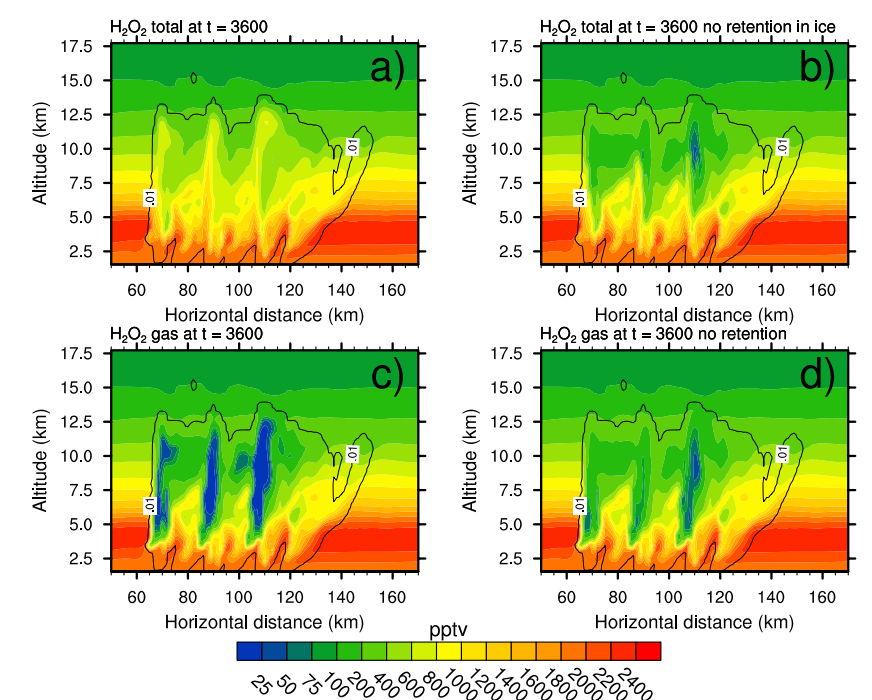

Fig. 14. STERAO case - results at $t=3600 \mathrm{~s}$ for vertical cross section of $\mathrm{H}_{2} \mathrm{O}_{2}$ mixing ratio in pptv along the segment indicated in Fig. 10a, left hand side, for simulation with retention in ice, and right hand side for the simulation without retention: (a) and (b) total mixing ratio, and (c) and (d) in gas phase. The black line represents the total hydrometeors mixing ratio equal to $0.01 \mathrm{~g} \mathrm{~kg}^{-1}$.

The same effect is observed for hydrogen peroxide (Fig. 14a and b). Moreover, as hydrogen peroxide is more soluble than HCHO in liquid water and is very reactive in aqueous phase with sulphur dioxide, its vertical transport from the boundary layer to the anvil is less efficient than for HCHO. A significant depletion is observed in the convective cores for hydrogen peroxide in gas phase for the simulation with retention in ice (Fig. 14c), underlying its capture in the ice phase. This depletion is also observed for the simulation without retention in ice (Fig. 14d), whereas this effect is not observed for HCHO (Fig. 12b). This difference stems from the very efficient transfer of hydrogen peroxide from the gas phase to the liquid phase due to its high reactivity and its high solubility in the aqueous phase.

As in Barth et al. (2007b), integrated results are shown as percentages of $\mathrm{HCHO}$ and $\mathrm{H}_{2} \mathrm{O}_{2}$ in each water chemical reservoir relative to the total amount of the species in the condensed phase (Fig. 15). The total amount of each of the hydrometeor reservoirs relative to the total amount of condensed water is also indicated (Fig. 15a). The transition between the multicell and the supercell stages of the storm is marked by the minimum of the percentage of cloud water between 90 and $120 \mathrm{~min}$. The percentage of the pristine ice reservoir is of the same order of magnitude as the graupel reservoir, whereas the proportion of ice was very small in Barth et al. (2007b), less than 5\%. Moreover, the amount of cloud water is greater than that of rainwater, in contrast to Barth et al.'s (2007b) findings. These differences come from the microphysical schemes used in the two models 


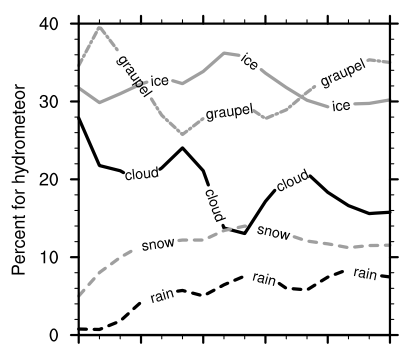

a)
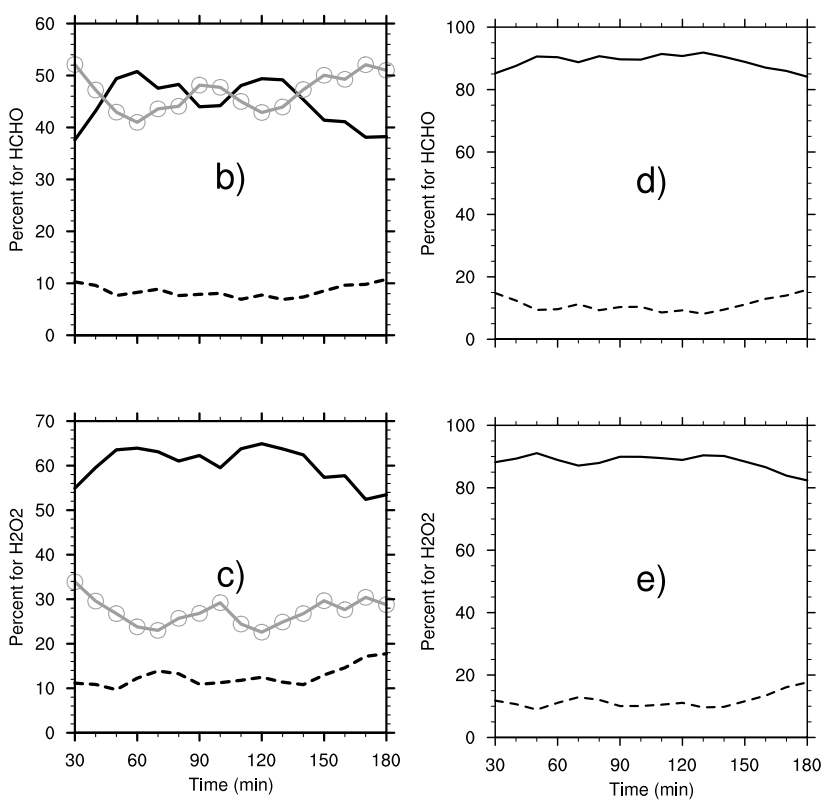

Fig. 15. STERAO case - results for the model domain as a function of time in the simulation sampled every $10 \mathrm{~min}$ : (a) percentage of each hydrometeor reservoir relative to the total amount of condensed water, (b) percentage of $\mathrm{HCHO}$ in each water category (cloud, rain, precipitating ice) relative to the total amount of $\mathrm{HCHO}$ in all the water reservoirs for simulation with retention in ice, $(\mathbf{c})$ the same for $\mathrm{H}_{2} \mathrm{O}_{2}$, (d) the same for $\mathrm{HCHO}$ but for simulation without retention in ice, and (e) the same for $\mathrm{H}_{2} \mathrm{O}_{2}$ but for the simulation without retention in ice. Solid and dashed black lines (b, c, d, e) are for cloud water and rainwater reservoirs, respectively. Grey line with open circles $(\mathbf{b}, \mathbf{c})$ is for the ice-precipitating reservoir.

with different parameterizations of microphysical processes and different ice phase categories. For instance, Barth et al. (2007b) used pristine ice, snow and hail as ice phase categories, whereas in Meso-NH the ICE3 scheme uses pristine ice, snow and graupel. Results for the vertical cross section across the anvil of ice particle concentration shown in Barth et al. (2007a) reflected these differences in the cloud microphysics schemes of the models participating in the intercomparison exercise, including WRF-Chem and Meso-NH. Looking at the simulation without retention in ice (Fig. 15d and e), the distributions of $\mathrm{HCHO}$ and $\mathrm{H}_{2} \mathrm{O}_{2}$ between cloud water and rainwater are seen to be very similar, in agreement with Barth et al. (2007b). For the simulation with retention in ice, the percentages of $\mathrm{HCHO}$ and $\mathrm{H}_{2} \mathrm{O}_{2}$ in rainwater are close. The percentage of $\mathrm{HCHO}$ in ice-precipitating hydrometeors is of the same order of magnitude as in cloud water (Fig. 15b), whereas the percentage of $\mathrm{H}_{2} \mathrm{O}_{2}$ in iceprecipitating hydrometeors is less than half of those in cloud water (Fig. 15c). This difference comes from the reactivity of the hydrogen peroxide in aqueous phase, leading to its destruction in cloud water and, thus, limiting its transfer to the ice phase in comparison to HCHO.

This 3-D idealized simulation, having already been run by several models, shows consistency of results obtained by Meso-NH, with similar features observed by Barth et al. (2007b), for instance. Moreover, this particular simulation underlines the potential role of the ice phase as a reservoir of soluble species that are unavailable to react in either gas or aqueous phases.

\section{Conclusions}

A cloud chemistry module has been developed in the mesoscale atmospheric model Meso-NH. This module is a complete suite that includes aqueous phase reactivity, exchange of chemical species between the gas phase and the condensed phase (liquid and ice), a diagnostic estimation of $\mathrm{pH}$ in cloud water and rainwater, and the redistribution of chemical species by mixed-phase cloud microphysical processes. The aqueous phase chemical mechanism was developed to be consistent with the available gas phase chemical mechanism ReLACS, which is a reduced form of the RACM mechanism. The exchange of chemical species between gas phase and aqueous phase has been considered using the theory of mass transfer kinetics, including the limitation of the solubility inside droplets by gas phase diffusion and accommodation at the air/water interface. The redistribution of chemical species by cloud microphysical processes has been developed for both one-moment and two-moment cloud microphysical schemes. Cloud microphysical processes include the autoconversion, the accretion and the sedimentation of all precipitating hydrometeors (rain, snow, graupel), and the freezing and the riming of supercooled drops. For these last processes, retention coefficients have been estimated to compute the amounts of soluble species retained in the ice and released in the gas phase. If the effect of an ice phase on chemical budgets is taken into account, prognostic scalar variables are added for the global mixing ratio of soluble species in ice-precipitating hydrometeors to save computing time. It is possible to run a simulation with mixed phase microphysics and without these additional prognostic variables, in which soluble chemical species are completely released to the gas phase when freezing or riming occurs.

The new cloud chemistry module has been tested on three cases. The first one is a 2-D simulation of a warm cumulus cloud formed over Hawaii Island. This case is used in 
particular to focus on the impact of a 1-moment cloud microphysics scheme vs. a 2-moment cloud microphysics scheme. Results show significant differences between the two microphysical approaches in terms of mixing ratios of chemical species. In particular, the 2-moment approach leads to smaller raindrops, thus limiting sulphuric acid formation inside the rain and leading to less acidic raindrops than for the 1-moment scheme.

The second case is a 2-D simulation of a tropical squall line observed in West Africa. When no retention in ice is considered, this case underlines the complex interactions between the degassing of soluble species from supercooled droplets and the transport of chemical species throughout the simulation. This leads to a release of soluble species, which are entrained by the convective updraft inside the anvil while the convective cell evolves in a squall line. When the retention in ice is taken into account, very low mixing ratios of soluble species inside the forward anvil and the stratiform part of the squall line are observed due to efficient trapping of soluble species inside the ice-precipitating hydrometeors, which then contribute to wet deposition.

The last test case is a 3-D idealized simulation of a storm observed in Colorado. First, the comparison of our results with those of Barth et al. (2007b), who used an explicit representation of the mixing ratio of soluble species in each ice phase hydrometer category, shows that the global approach for the ice phase species mixing ratio representation used in Meso-NH is comparable to a more explicit approach. The comparison of simulations considering or neglecting the retention of soluble species in ice shows a depletion of the gas phase mixing ratio of soluble species in the convective outflow for the simulation with retention in ice, whereas the simulation without retention shows enrichment in the anvil. This difference is due to the capture of soluble species in the ice phase. Also, a greater value of the total mixing ratio of the soluble species observed in the simulation with retention in ice, in comparison to simulation without retention, indicates a reservoir of the soluble species in the ice phase leading to lower concentration of soluble species available to react in gas- and aqueous phases. This effect is the inverse of the one observed for the COPT test case, showing inefficient wet deposition of soluble species due to the transfer of soluble species in rain from the ice-precipitating hydrometeors.

Results for COPT and STERAO cases on the amount of formaldehyde in the convective outflow show a depletion in comparison to the unperturbed UT. This result is consistent with previous modelling studies (Barth et al., 2007b; Marécal et al., 2006) and agrees with the hypothesis of an inefficient direct convective transport of HCHO to the upper troposphere (Stickler et al., 2006; Fried et al., 2008; Borbon et al., 2012). Unlike the observations reported in these works, however, the model does not show an increase of HCHO in the upper troposphere due to secondary production by vented VOC precursors. Moreover, the aqueous phase chemistry mechanism used in this study includes simple organic chemistry and neglects impacts of metal ions (e.g. Fe, $\mathrm{Cu}$ ) on the $\mathrm{HO}_{\mathrm{x}}$ budget, and thus might lead to a biased predicted aqueous phase $\mathrm{OH}$ concentration (Mao et al., 2013). In fact, measurements by other modelling studies have shown that aqueous phase $\mathrm{OH}$ concentrations in authentic cloud water are on the order of $5 \times 10^{-16} \mathrm{M}$ (Anastasio and McGregor, 2001), as opposed to $\sim 10^{-13} \mathrm{M}$ as predicted in our model, leading to an overestimation of the oxidation of $\mathrm{HCHO}$ in cloud droplets and raindrops. In order to try to understand the discrepancy between models and measurements for the amount of HCHO in the convective outflow, additional studies are needed based on well documented case studies (e.g. the AMMA experiment described in Borbon et al., 2012). Simulations of mixed-phase clouds show an important effect of retention that either acts as a reservoir (STERAO case) or as a sink through wet deposition (COPT case) for soluble species. Additional measurements of retention coefficients, both in real clouds and in the laboratory, are thus urgently needed in order to better constrain the partitioning of chemical species between all phases in mixed phase clouds. Ultimately, a physically-based method for assigning the retention coefficient has to be developed that takes into account all important factors identified by Start and Jacobson (2004).

An interesting extension of the cloud chemistry module of Meso-NH would consider coupling the present scheme with the explicit electrical scheme of Meso-NH (Barthe et al., 2012) in order to include the sporadic source of NO produced by the simulation of lightning flashes in deep convective storms.

The next step for the cloud chemistry module will be to include more complex organic chemistry in the aqueous phase coupled to the ReLACS2 gas phase mechanism (Tulet et al., 2006) available in Meso-NH. The ReLACS2 mechanism describes the gas phase chemistry of the ozone- $\mathrm{NO}_{\mathrm{x}}$-VOC system, including the formation of the gas phase semi-volatile precursors of SOA. The objective is to simulate the formation of the aqueous phase precursors of SOA in droplets, and to study the effect of aqueous phase reactivity on SOA formation in the troposphere.

Acknowledgements. Computer resources were provided by I.D.R.I.S. (Institut du Développement et des Ressources en Informatique Scientifique, project no. 90005). We acknowledge the IDAF project, which is an initiative of the IGBP (International Geosphere Biosphere Program) IGAC (International Global Atmospheric Chemistry) project and forms part of its core DEBITS (DEposition of Biogeochemically Important Trace Species) task. IDAF is supported by CNRS-INSU (Centre National de la Recherche Scientifique - Institut National des Sciences de l'Univers) and the OMP (Midi-Pyrénées Observatory) and also the IRD (Institut de Recherche pour le Développement). We wish to acknowledge the use of the NCAR Command Language (NCL, http://dx.doi.org/10.5065/D6WD3XH5, Boulder, Colorado) version 6.0.0 software for analysis and graphics in this paper. We are very grateful to Brice Barret for his help with the 
initialization of the COPT test case. We thank Christelle Barthe for her help on the STERAO case. Finally, many thanks to the whole Meso-NH team (Juan Escobar and Soline Bielli at LA, Pierre Tulet at LaCY, Chrisitne Lac and Gaëlle Tanguy at CNRM/GAME).

Edited by: H. Tost

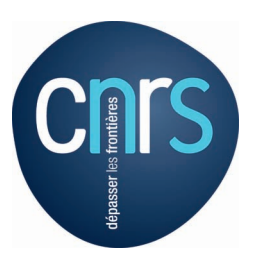

The publication of this article is financed by CNRS-INSU.

\section{References}

Adon, M., Galy-Lacaux, C., Yoboué, V., Delon, C., Lacaux, J. P., Castera, P., Gardrat, E., Pienaar, J., Al Ourabi, H., Laouali, D., Diop, B., Sigha-Nkamdjou, L., Akpo, A., Tathy, J. P., Lavenu, F., and Mougin, E.: Long term measurements of sulfur dioxide, nitrogen dioxide, ammonia, nitric acid and ozone in Africa using passive samplers, Atmos. Chem. Phys., 10, 7467-7487, doi:10.5194/acp-10-7467-2010, 2010.

Amels, P., Elias, H., Götz, U., Steinges, U., and Wannowius, K. J.: Kinetic investigation of the stability of peroxonitric acid and of its reaction with sulfur(IV) in aqueous solution, in: Heterogeneous and Liquid Phase Processes, Transport and Chemical Transformation of Pollutants in the Troposphere, edited by: Warneck, P., Vol. 2, Springer, Berlin, 77-88, 1996.

Anastasio, C. and McGregor, K. G.: Chemistry of fog waters in California's Central Valley: 1. In situ photo-formation of hydroxyl radical and singlet molecular oxygen, Atmos. Environ., 35, 1079-1089, 2001.

Audiffren, N., Renard, M., Buisson, E., and Chaumerliac, N.: Deviations from the Henry's law equilibrium during cloud events: a numerical approach of the mass transfer between phases and specific numerical effects, Atmos. Res., 49, 139-161, 1998.

Barker, G. C., Fowles, P., and Stringer, B.: Pulse radiolytic induced transient electrical conductance in liquid solutions of $\mathrm{NO}_{3}^{-}$, $\mathrm{NO}_{2}^{-}$, and $\mathrm{Fe}(\mathrm{CN})_{6}{ }^{3-}$, Trans. Faraday Soc., 66, 1509-1519, 1970.

Barth, M. C., Stuart, A. L., and Skamarock, W. C.: Numerical simulations of the July 10, 1996, Stratospheric-Tropospheric Experiment: Radiations, Aerosols, and Ozone (STERAO)-Deep Convection experiment storm: Redistribution of soluble tracers, J. Geophys. Res., 106, 12381-12400, 2001.

Barth, M. C., Kim, S.-W., Wang, C., Pickering, K. E., Ott, L. E., Stenchikov, G., Leriche, M., Cautenet, S., Pinty, J.-P., Barthe, Ch., Mari, C., Helsdon, J. H., Farley, R. D., Fridlind, A. M., Ackerman, A. S., Spiridonov, V., and Telenta, B.: Cloud-scale model intercomparison of chemical constituent transport in deep convection, Atmos. Chem. Phys., 7, 4709-4731, doi:10.5194/acp-74709-2007, 2007a.

Barth, M. C., Kim, S.-W., Skamarock, W. C., Stuart, A. L., Pickering, K. E., and Ott, L. E.: Simulations of the redistribution of formaldehyde, formic acid, and peroxides in the 10 July 1996 Stratospheric-Tropospheric Experiment: Radiation, Aerosols, and Ozone deep convection storm, J. Geophys. Res.,
112, D13310, doi:10.1029/2006JD008046, 2007 b.

Barthe, C., Chong, M., Pinty, J.-P., Bovalo, C., and Escobar, J.: CELLS v1.0: updated and parallelized version of an electrical scheme to simulate multiple electrified clouds and flashes over large domains, Geosci. Model Dev., 5, 167-184, doi:10.5194/gmd-5-167-2012, 2012.

Bechtold, P., Bazile, E., Guichard, F., Mascart, P., and Richard, E.: A mass-flux convection scheme for regional and global models, Q. J. Roy. Meteor. Soc., 127, 869-886, 2001.

Becker, K. H., Klemmann, R., Kurtenbach, R., and Wiesen, P.: Solubility of nitrous acid (HONO) in sulfuric acid solutions, J. Phys. Chem., 100, 14984-14990, 1996.

Bell, R. P.: The reversible hydration of carbonyl compounds, Advanc. Phys. Orga. Chem., 4, 1-29, 1966.

Berthet, S., Leriche, M., Pinty, J. -P., Cuesta, J., and Pigeon, G.: Scavenging of aerosol particles by rain in a cloud resolving model, Atmos. Res., 96, 325-336, 2010.

Bielski B. H. J., Cabelli, D. E., Arudi, R. L., and Ross, A. B.: Reactivity of $\mathrm{HO}_{2} / \mathrm{O}_{2}^{-}$in aqueous solution, J. Phys. Chem. Ref. Data, 14, 1041-1100, 1985.

Bongartz, A., Kames, J., Schurath, U., George, C., Mirabel, P., and Ponche, J. L.: Experimental determination of HONO mass accommodation coefficients using two different techniques, J. Atmos. Chem., 18, 149-170, 1994.

Borbon, A., Ruiz, M., Bechara, J., Aumont, B., Chong, M., Huntrieser, H., Mari, C., Reeves, C. E., Scialom, G., Hamburger, T., Stark, H., Afif, C., Jambert, C., Mills, G., Schlager, H., and Perros, P. E.: Transport and chemistry of formaldehyde by mesoscale convective systems in West Africa during AMMA 2006, J. Geophys. Res., 117, D12301, doi:10.1029/2011JD017121, 2012.

Bousserez, N., Attie, J.-L., Peuch, V.-H, Michou, M., Pfister, G., Edwards, D., Emmons, L., Mari, C., Barret, B., Arnold, S. R., Heckel, A., Richter, A., Schlager, H., Lewis, A., Avery, M., Sachse, G., Browell, E. V., and Hair, J. W.: Evaluation of the MOCAGE chemistry transport model during the ICARTT/ITOP experiment, J. Geophys. Res., 112, D10S42, doi:10.1029/2006JD007595, 2007.

Buxton, G. V., McGowan, S., Salmon, G. A., Williams, J. E., and Wood, N. D.: A study of the spectra and reactivity of oxysulphur radical anions involved in the chain oxidation of $\mathrm{S}(\mathrm{IV})$ : a pulse and $\gamma$-radiolysis study, Atmos. Environ., 30, 2483-2493, 1996.

Caniaux, G., Redelsperger, J.-L., and Lafore, J.-P.: A numerical study of the stratiform region of a fast-moving squall line, Part I: General description and water and heat budgets, J. Atmos. Sci., 51, 2046-2074, 1994.

Chang, J. S., Brost, R. A., Isaksen, I. S. A., Madronich, S., Middleton, P., Stockwell, W. R., and Walcek, C. J.: A three-dimensional Eulerian acid deposition model: Physical concepts and formulation, J. Geophys. Res., 92, 14681-14700, 1987.

Chen, J., Griffin, R. J., Grini, A., and Tulet, P.: Modeling secondary organic aerosol formation through cloud processing of organic compounds, Atmos. Chem. Phys., 7, 5343-5355, doi:10.5194/acp-7-5343-2007, 2007.

Chin, M. and Wine, P. H.: A temperature-dependent competitive kinetics study of the aqueous-phase reactions of $\mathrm{OH}$ radicals with formate, formic acid, acetate, acetic acid, and hydrated formaldehyde, in: Aquatic and Surface Photochemistry, edited by: Helz, G. R., Zepp, R. G., and Crosby, D. G., CRC Press, Boca Raton, 
85-98, 1994.

Christensen, $\mathrm{H}$. and Sehested, $\mathrm{K} .: \mathrm{HO}_{2}$ and $\mathrm{O}_{2}^{-}$radicals at elevated temperatures, J. Phys. Chem., 92, 3007-3011, 1988.

Cohan, D. S., Schultz, M. G., Jacob, D. J., Heikes, B. G., and Blake, D. R.: Convective injection and photochemical decay of peroxides in the tropical upper troposphere: Methyl iodide as a tracer of marine convection, J. Geophys. Res., 104, 5717-5724, doi:10.1029/98JD01963, 1999.

Cohard, J.-M. and Pinty, J. -P.: A comprehensive two-moment warm microphysical bulk scheme. Part I: Description and selective tests, Q. J. R. Meteorol. Soc., 126, 1815-1842, 2000a.

Cohard, J.-M. and Pinty, J.-P.: A comprehensive two-moment warm microphysical bulk scheme, Part II: 2-D experiments with a nonhydrostatic model, Q. J. R. Meteorol. Soc., 126, 1843-1859, 2000 b.

Cohard, J.-M., Pinty, J. -P., and Bedos, C.: Extending Twomey's analytical estimate of nucleated cloud droplet concentrations from CCN spectra, J. Atmos. Sci., 55, 3348-3357, 1998.

Crassier, V., Suhre, K., Tulet, P., and Rosset, R.: Development of a reduced chemical scheme for use in mesoscale meteorological models, Atmos. Environ., 34, 2633-2644, 2000.

Cuxart, J., Bougeault, P., and Redelsperger, J.-L.: A turbulence scheme allowing for mesoscale and large-eddy simulations, Q. J. Roy. Meteorol. Soc., 126, 1-30, 2000.

Damian, V., Sandu, A., Damian, M., Potra, F., and Carmichael, G. R.: The kinetic preprocessor KPP - a software environment for solving chemical kinetics, Comput. Chem. Eng., 26, 1567-1579, 2002.

Das, T. N.: Reactivity and role of $\mathrm{SO}_{5}{ }^{-}$- radical in aqueous medium chain oxidation of sulfite to sulfate and atmospheric sulfuric acid generation, J. Phys. Chem. A, 105, 9142-9155, 2001.

Davidovits, M., Hu, J. H., Worsnop, D. R., Zahniser, M. S., and Kolb, C. E.: Entry of gas molecules into liquids, Faraday Discus., 100, 65-82, 1995.

Dickerson, R. R., Huffman, G. J., Luke, W. T., Nunnermacker, L. J., Pickering, K. E., Leslie, A. C. D., Lindsey, C. G., Slinn, W. G. N., Kelly, T. J., Daum, P. H., Delany, A. C., Greenberg, J. P., Zimmerman, P. R., Boatman, J. F., Ray, J. D., and Stedman, D. H.: Thunderstorms: An important mechanism in the transport of pollutants, Science, 237, 460-465, 1987.

Dye, J. E., Ridley, B. A., Baumann, K., Skamarock, W. C., Barth, M. C., Venticinque, M., Defer, E., Blanchet, P., Thery, C., Laroche, P., Hubler, G., Parrish, D. D., Ryerson, T., Trainer, M., Frost, G., Holloway, J. S., Fehsenfeld, F. C., Tuck, A., Matejka, T., Bartels, D., Rutledge, S. A., Lang, T., Stith, J., and Zerr, R.: An Overview of the STERAO-Deep Convection Experiment with Results for the 10 July Storm, J. Geophys. Res., 105, 10023-10045, 2000.

Elliot, A. J.: A pulse radiolysis study of the temperature dependence of the reactions involving $\mathrm{H}, \mathrm{OH}$ and $\mathrm{e}_{a q}^{-}$in aqueous solutions, Radiat. Phys. Chem., 34-5, 753-758, 1989.

Elliot, A. J. and Buxton, G.: Temperature dependence of the reactions $\mathrm{OH}+\mathrm{O}_{2}^{-}$and $\mathrm{OH}+\mathrm{HO}_{2}$ in water up to $200^{\circ} \mathrm{C}$, J. Chem. Soc. Faraday Transac., 88, 2465-2470, 1992.

Ervens, B., George, C., Williams, J. E., Buxton, G. V., Salmon, G. A., Bydder, M., Wilkinson, F., Dentener, F., Mirabel, P., and Herrmann, H.: CAPRAM 2.4 (MODAC mechanism): An extended and condensed tropospheric aqueous phase mechanism and its application, J. Geophys. Res., 108, 4426, doi:10.1029/2002JD002202, 2003.
Ervens, B., Turpin, B. J., and Weber, R. J.: Secondary organic aerosol formation in cloud droplets and aqueous particles (aqSOA): a review of laboratory, field and model studies, Atmos. Chem. Phys., 11, 11069-11102, doi:10.5194/acp-1111069-2011, 2011.

Exner, M., Herrmann, H., and Zellner, R.: Laser-based studies of reactions of the nitrate radical in aqueous solution, Ber. Bunsenges. Phys. Chem., 96-3, 470-477, 1992.

Finlayson-Pitts, B. J. and Pitts, J. N.: Chemistry of the Upper and Lower Atmosphere: Theory, Experiments, and Applications, Academic Press, San Diego, USA, 969 pp., 2000.

Flossmann, A. I., and Wobrock, W.: Venting of gases by convective clouds, J. Geophys. Res., 101, 18639-18650, 1996.

Fried, A., Henry, B. E., Calvert, J. G., and Mozurkewich, M.: The reaction probability of $\mathrm{N}_{2} \mathrm{O}_{5}$ with sulfuric acid aerosols at stratospheric temperatures and composition, J. Geophys. Res., 99, 3517-3532, 1994.

Fried, A., Olson, J. R., Walega, J. G., Crawford, J. H., Chen, G., Weibring, P., Richter, D., Roller, C., Tittel, F., Porter, M., Fuelberg, H., Halland, J., Bertram, T. H., Cohen, R. C., Pickering, K., Heikes, B. G., Snow, J. A., Shen, H., O’Sullivan, D. W., Brune, W. H., Ren, X., Blake, D. R., Blake, N., Sachse, G., Diskin, G. S., Podolske, J., Vay, S. A., Shetter, R. E., Hall, S. R., Anderson, B. E., Thornhill, L., Clarke, A. D., McNaughton, C. S., Singh, H. B., Avery, M. A., Huey, G., Kim, S., and Millet, D. B.: Role of convection in redistributing formaldehyde to the upper troposphere over North America and the North Atlantic during the summer 2004 INTEX campaign, J. Geophys. Res., 113, D17306, doi:10.1029/2007JD009760, 2008.

George, C., Ponche, J. L., Mirabel, P., Behnke, W., Scheer, V., and Zetzsch, C.: Study of uptake of $\mathrm{N}_{2} \mathrm{O}_{5}$ by water and $\mathrm{NaCl}$ solutions, J. Phys. Chem., 98, 8780-8784, 1994.

Goldstein, S. and Czapski, G.: Reactivity of peroxynitric acid $\left(\mathrm{O}_{2} \mathrm{NOOH}\right)$ : A pulse radiolysis study, Inorg. Chem., 36, 41564162, 1997.

Goldstein, S., Czapski, G., Lind, J., and Merenyi, G.: Mechanism of decomposition of peroxynitric ion $\left(\mathrm{O}_{2} \mathrm{NOO}^{-}\right)$: evidence for the formation of $\mathrm{O}_{2}{ }^{-}$and $\mathrm{NO}_{2}$ radicals, Inorg. Chem., 37, 39433947, 1998.

Graedel, T. E. and Weschler, C. J.: Chemistry within aqueous atmospheric aerosols and raindrops, Rev. Geophys. Space Phys., 19, 505-539, 1981.

Hallquist, M., Wenger, J. C., Baltensperger, U., Rudich, Y., Simpson, D., Claeys, M., Dommen, J., Donahue, N. M., George, C., Goldstein, A. H., Hamilton, J. F., Herrmann, H., Hoffmann, T., Iinuma, Y., Jang, M., Jenkin, M. E., Jimenez, J. L., Kiendler-Scharr, A., Maenhaut, W., McFiggans, G., Mentel, Th. F., Monod, A., Prévôt, A. S. H., Seinfeld, J. H., Surratt, J. D., Szmigielski, R., and Wildt, J.: The formation, properties and impact of secondary organic aerosol: current and emerging issues, Atmos. Chem. Phys., 9, 5155-5236, doi:10.5194/acp-9-51552009, 2009.

Herrmann, H.: Kinetics of aqueous phase relevant for atmospheric chemistry, Chem. Rev., 103, 4691-4716, 2003.

Herrmann, H., Reese, A., Ervens, B., Wicktor, F., and Zellner, R.: Laboratory and modelling studies of tropospheric multiphase conversions involving some $\mathrm{C} 1$ and $\mathrm{C} 2$ peroxyl radicals, Phys. Chem. Earth, 24, 287-290, 1999. 
Hindmarsh, A. C.: ODEPACK, a systematized collection of ODE solvers, in: Scientific Computing, edited by: Stepleman, R. S., North-Holland, Amsterdam, 55-64, 1983.

Iribarne, J. V. and Pyshnov, T.: The effect of freezing on the composition of the supercooled droplets, I: Retention of $\mathrm{HCl}, \mathrm{HNO}_{3}$, $\mathrm{NH}_{3}$, and $\mathrm{H}_{2} \mathrm{O}_{2}$, Atmos. Environ., 24A, 383-387, 1990a.

Iribarne, J. V. and Pyshnov, T.: The effect of freezing on the composition of the supercooled droplets, II: Retention of S(IV), Atmos. Environ., 24A, 389-398, 1990b.

Jaeglé, L., Jacob, D. J., Wennberg, P. O., Spivakosky, C. M., Hanisco, T. F., Lanzendorf, E. J., Hintsa, E. J., Fahey, D. W., Keim, E. R., Proffitt, M. H., Atlas, E. L., Flocke, F. M., Schauffler, S. M., McElroy, C. T., Midwinter, C., Pfister, L., and Wilson, J. C.: Observed $\mathrm{OH}$ and $\mathrm{HO}_{2}$ in the upper troposphere suggest a major source from convective injection of peroxides, Geophys. Res. Lett., 24, 3181-3184, 1997.

Jaeglé, L., Jacob, D. J., Brune, W. H., Tan, D., Faloona, I. C., Weinheimer, A. J., and Sachse, G. W.: Sources of $\mathrm{HO}_{\mathrm{x}}$ and production of ozone in the upper troposphere over the United States, Geophys. Res. Lett., 25, 1709-1712, 1998.

Jaeglé, L., Jacob, D. J., Brune, W. H., and Wennberg, P. O.: Chemistry of $\mathrm{HO}_{\mathrm{x}}$ radicals in the upper troposphere, Atmos. Environ., 35, 469-489, 2001.

Kanakidou, M., Seinfeld, J. H., Pandis, S. N., Barnes, I., Dentener, F. J., Facchini, M. C., Van Dingenen, R., Ervens, B., Nenes, A., Nielsen, C. J., Swietlicki, E., Putaud, J. P., Balkanski, Y., Fuzzi, S., Horth, J., Moortgat, G. K., Winterhalter, R., Myhre, C. E. L., Tsigaridis, K., Vignati, E., Stephanou, E. G., and Wilson, J.: Organic aerosol and global climate modelling: a review, Atmos. Chem. Phys., 5, 1053-1123, doi:10.5194/acp-5-1053-2005, 2005.

Kessler, E.: On the distribution and continuity of water substance in atmospheric circulations, Meteor. Monogr., No. 10, Amer. Meteor. Soc., Boston, 84 pp., 1969.

Khairoudinov, M. and Kogan, Y.: A new cloud physics parameterization in a large-eddy simulation model of marine stratocumulus, Mon. Weather Rev., 128, 229-243, 2000.

Lamb, D. and Blumenstein, R.: Measurements of the entrapment of sulphur dioxide by rime ice, Atmos. Environ., 21, 1765-1772, 1987.

Lafore, J. P., Stein, J., Asencio, N., Bougeault, P., Ducrocq, V., Duron, J., Fischer, C., Héreil, P., Mascart, P., Masson, V., Pinty, J. P., Redelsperger, J. L., Richard, E., and Vilà-Guerau de Arellano, J.: The Meso-NH Atmospheric Simulation System. Part I: adiabatic formulation and control simulations, Ann. Geophys., 16, 90-109, doi:10.1007/s00585-997-0090-6, 1998.

Lawrence, M. G. and Crutzen, P. J.: The impact of cloud particle gravitational settling on soluble trace gas distributions, Tellus, 50B-3, 263-289, 1998.

Lelieveld, J. and Crutzen, P. J.: The role of clouds in tropospheric photochemistry, J. Atmos. Chem., 12, 229-267, 1991.

Leriche, M., Voisin, D., Chaumerliac, N., Monod, A., and Aumont, B.: A model for tropospheric multiphase chemistry: Application to one cloudy event during the CIME experiment, Atmos. Environ., 34, 5015-5036, 2000.

Leriche, M., Deguillaume, L., and Chaumerliac, N.: Modeling study of strong acids formation and partitioning in a polluted cloud during wintertime, J. Geophys. Res., 108, 4433, doi:10.1029/2002JD002950, 2003.
Lim, Y. B., Tan, Y., Perri, M. J., Seitzinger, S. P., and Turpin, B. J.: Aqueous chemistry and its role in secondary organic aerosol (SOA) formation, Atmos. Chem. Phys., 10, 1052110539, doi:10.5194/acp-10-10521-2010, 2010.

Logager, T. and Sehested, K.: Formation and decay of peroxynitric acid: A pulse radiolysis study, J. Phys. Chem., 97, 10047-10052, 1993.

Logager, T., Sehested, K., and Holoman, J.: Rate constants of the equilibrium reactions $\mathrm{SO}_{4}^{-}+\mathrm{HNO}_{3} \leftrightarrow \mathrm{HSO}_{4}^{-}+\mathrm{NO}_{3}$ and $\mathrm{SO}_{4}{ }^{-}+\mathrm{NO}_{3}{ }^{-} \leftrightarrow \mathrm{SO}_{4}{ }^{2-}+\mathrm{NO}_{3}$, Radiat. Phys. Chem., 41, 539543, 1993.

Long, Y., Chaumerliac, N., Deguillaume, L., Leriche, M., and Champeau, F.: Effect of mixed phase cloud on the chemical budget of trace gases: a modeling approach, Atmos. Res., 97, 540554, 2010.

Maaß, F., Elias, H., and Wannowius, K. J.: Kinetics of oxidation of hydrogen sulfite by hydrogen peroxide in aqueous solution: ionic strength effects and temperature dependence, Atmos. Environ., 33, 4413-4419, 1999.

Madronich, S. and Flocke, S.: The role of solar radiation in atmospheric chemistry, in: Handbook of Environmental Chemistry, edited by: Boule, P., Springer-Verlag, Heidelberg, 1-26, 1999.

Mao, J., Fan, S., Jacob, D. J., and Travis, K. R.: Radical loss in the atmosphere from $\mathrm{Cu}-\mathrm{Fe}$ redox coupling in aerosols, Atmos. Chem. Phys., 13, 509-519, doi:10.5194/acp-13-509-2013, 2013.

Marécal, V., Rivière, E. D., Held, G., Cautenet, S., and Freitas, S.: Modelling study of the impact of deep convection on the utls air composition - Part I: Analysis of ozone precursors, Atmos. Chem. Phys., 6, 1567-1584, doi:10.5194/acp-6-1567-2006, 2006.

Mari, C., Suhre, K., Rosset, R., Bates, T. S., Huebert, B. J., Bandy, A. R., Thornton, D. C., and Businger, S.: One-dimensional modeling of sulfur species during the First Aerosol Characterization Experiment (ACE 1) Lagrangian B, J. Geophys. Res., 104, 21733-21749, 1999.

Mari, C., Jacob, D. J., and Bechtold, P.: Transport and scavenging of soluble gases in a deep convective cloud, J. Geophys. Res., 105, 22255-22267, 2000.

Mari, C., Saüt, C., Jacob, D. J., Staudt, A., Avery, M. A., Brune, W. H., Faloona, I., Heikes, B. G., Sachse, G. W., Sandholm, S. T., Singh, H. B., and Tan, D.: On the relative role of convection, chemistry, and transport over the South Pacific Convergence Zone during PEM-Tropics B: A case study, J. Geophys. Res., 108, 8232, doi:10.1029/2001JD001466, 2003.

Masson, V.: A physically-based scheme for the urban energy budget in atmospheric models, Bound. Lay. Meteorol., 1994, 357-397, 2000.

Monod, A. and Carlier, P.: Impact of clouds on the tropospheric ozone budget: Direct effect of multiphase photochemistry of soluble organic compounds, Atmos. Environ., 33, 4431-4446, 1999.

Noilhan, J. and Mahfouf, J.: The ISBA land surface parameterization scheme, Glob. Planet. Change, 13, 145-159, 1996.

Olson, T. M. and Hoffmann, M. R.: Hydroxyalkylsulfonate formation: its role as a $\mathrm{S}(\mathrm{IV})$ reservoir in atmospheric water droplets, Atmos. Environ., 23, 985-997, 1989.

Park, J. Y. and Lee, Y.-N.: Solubility and decomposition kinetics of nitrous acid in aqueous solution, J. Phys. Chem., 92, 6294-6302, 1988. 
Paulot, F., Wunch, D., Crounse, J. D., Toon, G. C., Millet, D. B., DeCarlo, P. F., Vigouroux, C., Deutscher, N. M., González Abad, G., Notholt, J., Warneke, T., Hannigan, J. W., Warneke, C., de Gouw, J. A., Dunlea, E. J., De Mazière, M., Griffith, D. W. T., Bernath, P., Jimenez, J. L., and Wennberg, P. O.: Importance of secondary sources in the atmospheric budgets of formic and acetic acids, Atmos. Chem. Phys., 11, 1989-2013, doi:10.5194/acp-11-1989-2011, 2011.

Pergaud, J., Masson, V. Malardel, S., and Couvreux, F.: A parameterization of dry thermals and shallow cumuli for mesoscale numerical weather prediction, Bound.-Lay. Meteorol., 132, 83106, 2009.

Perrin, D. D.: Ionization constants of inorganic acids and bases in aqueous solution, Second Edition, Pergamon, Oxford, 1982.

Pickering, K. E., Wang, Y., Tao, W. K, Price, C., and Müller, J. F.: Vertical distributions of lightning $\mathrm{NO}_{\mathrm{x}}$ for use in regional and global chemical transport models, J. Geophys. Res., 103, 31203 31212, 1998.

Pinty, J.-P. and Jabouille, P.: A mixed-phase cloud parameterization for use in mesoscale non-hydrostatic model: simulations of a squall line and of orographic precipitations, Proc. Conf. of Cloud Physics, Everett, WA, USA, Amer. Meteor. Soc., Aug. 1999, 217-220, 1998

Prather, M. J. and Jacob, D. J.: A persistent imbalance in $\mathrm{HO}_{\mathrm{x}}$ and $\mathrm{NO}_{\mathrm{x}}$ photochemistry of the upper troposphere driven by deep tropical convection, Geophys. Res. Lett., 24, 3189-3192, 1997.

Press, W. H., Teukolsky, S. A., Vetterling, W. T., and Flannery, B. P.: Numerical Recipes 3rd Edn, The Art of Scientific Computing, Cambridge University Press, New York, USA, 1256 pp., 2007.

Pruppacher, H. R. and Klett, J. D.: Microphysics of clouds and precipitation, 2nd Edn., Kluwer Academic Publishers, Dordrecht, The Netherlands, 954 pp., 1997.

Régimbal, J.-M. and Mozurkewich, M.: Peroxynitric acid decay mechanisms and kinetics at low pH, J. Phys. Chem. A, 101, 8822-8829, 1997.

Sander, S. P., Finlayson-Pitts, B. J., Friedl, R. R., Golden, D. M., Huie, R. E., Keller-Rudek, H., Kolb, C. E., Kurylo, M. J., Molina, M. J., Moortgat, G. K., Orkin, V. L., Ravishankara, A. R., and Wine, P. H.: Chemical Kinetics and Photochemical Data for Use in Atmospheric Studies, Evaluation Number 15, JPL Publication 06-2, Jet Propulsion Laboratory, Pasadena, 2006.

Sandu, A. and Sander, R.: Technical note: Simulating chemical systems in Fortran90 and Matlab with the Kinetic PreProcessor KPP-2.1, Atmos. Chem. Phys., 6, 187-195, doi:10.5194/acp-6187-2006, 2006.

Sandu, A., Verwer, J. G., Van Loon, M., Carmichael, G. R., Potra, F. A., Dabdub, D., and Seinfeld, J. H.: Benchmarking stiff ode solvers for atmospheric chemistry problems II: Rosenbrock solvers, Atmos. Environ., 31, 3459-3472, $1997 \mathrm{~b}$.

Schwartz, S. E.: Mass-transport considerations pertinent to aqueous phase reactions of gases in liquid water clouds, in: Chemistry of Multiphase Atmospheric Systems, NATO ASI Series, G6, edited by: Jaeschke, W., Spinger-Verlag, The Netherlands, 415-471, 1986

Schwartz, S. E. and White, W. H.: Solubility equilibria of the nitrogen oxides and oxiacids in dilute aqueous solution, Adv. Environ. Sci. Engin., 4, 1-45, 1981.

Seinfeld, J. H. and Pandis, S. N.: Atmospheric chemistry and physics - from air pollution to climate change, Wiley-
Interscience, New York, 1998.

Serjeant, E. P. and Dempsey, B.: Ionization constants of organic acids in aqueous solution, Pergamon, Oxford, 1979.

Skamarock,W. C., Powers, J., Barth, M. C., Dye, J. E., Matejka, T., Bartels, D., Baumann, K., Stith, J., Parrish, D. D., and Hubler, G.: Numerical simulations of the 10 July STERAO/Deep Convection Experiment convective system: Kinematics and transport, J. Geophys. Res., 105, 19973-19990, 2000.

Snider, J. R. and Huang, J.: Factors influencing the retention of hydrogen peroxide and molecular oxygen in rime ice, J. Geophys. Res., 103, 1405-1415, 1998

Snider, J. R., Montague, D. C., and Vali, G.: Hydrogen peroxide retention in rime ice, J. Geophys. Res., 97, 7569-7578, 1992.

Stickler, A., Fischer, H., Williams, J., de Reus, M., Sander, R., Lawrence, M. G., Crowley, J. N., and Lelieveld, J.; Influence of summertime deep convection on formaldehyde in the middle and upper troposphere over Europe, J. Geophys. Res., 111, D14308, doi:10.1029/2005JD007001, 2006.

Stone, D., Evans, M. J., Commane, R., Ingham, T., Floquet, C. F. A., McQuaid, J. B., Brookes, D. M., Monks, P. S., Purvis, R., Hamilton, J. F., Hopkins, J., Lee, J., Lewis, A. C., Stewart, D., Murphy, J. G., Mills, G., Oram, D., Reeves, C. E., and Heard, D. E.: $\mathrm{HO}_{\mathrm{x}}$ observations over West Africa during AMMA: impact of isoprene and $\mathrm{NO}_{\mathrm{x}}$, Atmos. Chem. Phys., 10, 9415-9429, doi:10.5194/acp-10-9415-2010, 2010.

Stuart, A. L. and Jacobson, M. Z.: Chemical retention during dry growth riming, J. Geophys. Res., 109, D07305, doi:10.1029/2003JD004197, 2004.

Suhre, K., Crassier, V., Mari, C., Rosset, R., Johnson, D. W., Osborne, S., Wood, R., Andreae, M. O., Bandy, B., Bates, T. S. Businger, S., Gerbig, C., Raes, F., and Rudolph, J.: Chemistry and aerosols in the marine boundary layer: 1-D modelling of the three ACE-2 Lagrangian experiments, Atmos. Environ., 34 5079-5094, 2000.

Szumowski, M., Grabowki, W. W., and Ochs, H. T.: A simple twodimensional kinematic framework designed to test warm rain microphysical models, Atmos. Res., 45, 299-326, 1998.

Teyssèdre, H., Michou, M., Clark, H. L., Josse, B., Karcher, F., Olivié, D., Peuch, V.-H., Saint-Martin, D., Cariolle, D., Attié, J.-L., Nédélec, P., Ricaud, P., Thouret, V., van der A, R. J., VolzThomas, A., and Chéroux, F.: A new tropospheric and stratospheric Chemistry and Transport Model MOCAGE-Climat for multi-year studies: evaluation of the present-day climatology and sensitivity to surface processes, Atmos. Chem. Phys., 7, 58155860, doi:10.5194/acp-7-5815-2007, 2007.

Tost, H., Jöckel, P., Kerkweg, A., Pozzer, A., Sander, R., and Lelieveld, J.: Global cloud and precipitation chemistry and wet deposition: tropospheric model simulations with ECHAM5/MESSy1, Atmos. Chem. Phys., 7, 2733-2757, doi:10.5194/acp-7-2733-2007, 2007.

Tost, H., Lawrence, M. G., Brïhl, C., Jöckel, P., The GABRIEL Team, and The SCOUT-O3-DARWIN/ACTIVE Team: Uncertainties in atmospheric chemistry modelling due to convection parameterisations and subsequent scavenging, Atmos. Chem. Phys., 10, 1931-1951, doi:10.5194/acp-10-1931-2010, 2010.

Tulet, P., Crassier, V., Solmon, F., Guedalia, D., and Rosset, R.: Description of the mesoscale nonhydrostatic chemistry model and application to a transboundary pollution episode between northern France and southern England, J. Geophys. Res., 108, 4021, 
doi:10.1029/2000JD000301, 2003.

Tulet, P., Crassier, V., Cousin, F., Shure, K., and Rosset, R.: ORILAM, a three moment lognormal aerosol scheme for mesoscale atmospheric model. On-line coupling into the MesoNH-C model and validation on the Escompte campaign, J. Geophys. Res., 110, D18201, doi:10.1029/2004JD005716, 2005.

Tulet, P., Grini, A., Griffin, R., and Petitcol, S.: ORILAM-SOA: a computationally efficient model for predicting secondary organic aerosols in 3-D atmospheric models, J. Geophys. Res., 111, D23208, doi:10.1029/2006JD007152, 2006.

Twomey, S.: The nuclei of natural cloud formation. Part II: The supersaturation in natural clouds and the variation of cloud droplet concentration, Geophys. Pure Appl., 43, 243-249, 1959.

Voisin, D., Legrand, M., and Chaumerliac, N.: Scavenging of acidic gases $\left(\mathrm{HCOOH}, \mathrm{CH}_{3} \mathrm{COOH}, \mathrm{HNO}_{3}, \mathrm{HCl}\right.$, and $\left.\mathrm{SO}_{2}\right)$ and ammonia in mixed liquid-solid water clouds at the Puy de Dôme mountain (France), J. Geophys. Res., 105, 6817-6835, 2000.

von Blohn, N., Diehl, K., Mitra, S. K., and Borrmann, S.: Wind tunnel experiments on the retention of trace gases during riming: nitric acid, hydrochloric acid, and hydrogen peroxide, Atmos. Chem. Phys., 11, 11569-11579, doi:10.5194/acp-1111569-2011, 2011.

Waddicor, D. A., Vaughan, G., Choularton, T. W., Bower, K. N., Coe, H., Gallagher, M., Williams, P. I., Flynn, M., Volz-Thomas, A., Pätz, H. -W., Isaac, P., Hacker, J., Arnold, F., Schlager, H., and Whiteway, J. A.: Aerosol observations and growth rates downwind of the anvil of a deep tropical thunderstorm, Atmos. Chem. Phys., 12, 6157-6172, doi:10.5194/acp-12-6157-2012, 2012.
Wennberg, P. O., Hanisco, T. F., Jaeglé, L., Jacob, D. J., Hintsa, E. J., Lanzendorf, E. J., Anderson, J. G., Gao, R., Keim, E. R., Donnelly, S. G., Negro, L. A. D., Fahey, D. W., McKeen, S. A., Salawitch, R. J., Webster, C. R., May, R. D., Herman, R. L., Proffitt, M. H., Margitan, J. J., Atlas, E. L., Schauffler, S. M., Flocke, F., McElroy, C. T., and Bui, T. P.: Hydrogen radicals, nitrogen radicals, and the production of $\mathrm{O}_{3}$ in the upper troposphere, Science, 279, 49-53, 1998.

Yin, Y., Carslaw, K. S., and Parker, D. J.: Redistribution of trace gases by convective clouds - mixed-phase processes, Atmos. Chem. Phys., 2, 293-306, doi:10.5194/acp-2-293-2002, 2002.

Yu, X.-Y. and Barker, J. R.: Hydrogen peroxide photolysis in acidic solutions containing chloride ions, I. Chemical mechanism, J. Phys. Chem. A, 107, 1313-1324, 2003.

Yu, X.-Y., Bao, Z.-C., and Barker, J. R.: Free radical reactions involving $\mathrm{Cl}, \mathrm{Cl}_{2}{ }^{-}$, and $\mathrm{SO}_{4}{ }^{-}$in the $248 \mathrm{~nm}$ photolysis of aqueous solutions containing $\mathrm{S}_{2} \mathrm{O}_{8}^{2-}$ and $\mathrm{Cl}^{-}$, J. Phys. Chem. A, 108-2, 295-308, 2004.

Zellner, R., Exner, M., and Herrmann, H.: Absolute OH quantum yields in the laser photolysis of nitrate, nitrite and dissolved $\mathrm{H}_{2} \mathrm{O}_{2}$ at 308 and $351 \mathrm{~nm}$ in the temperature range $278-353 \mathrm{~K}$, J. Atmos. Chem., 10, 411-425, 1990. 